[RAdiocarbon, Vol 23, No. 2, 1981, P 252-304]

\title{
SCOTTISH UNIVERSITIES RESEARCH AND \\ REACTOR CENTRE RADIOCARBON MEASUREMENTS IV
}

\author{
D D HARKNESS
}

\author{
NERC Radiocarbon Laboratory \\ Scottish Universities Research and Reactor Centre \\ East Kilbride, Scotland
}

INTRODUCTION

Results reported here are for samples of geologic or geographic context completed during the period 1975 to 1978.

Analytic procedures have remained as described in R, 1973, v 15, p 554 to 565. The approach taken in the calculation and reporting of results ( $R, 1979$, v 21, p 203 to 256) has also been retained with the exception that, in keeping with the suggestion by Stuiver and Polach ( $\mathrm{R}, 1977, \mathrm{v} 19$, p 355 to 363), radiometric enrichment values that cannot be independently age-correlated are, where appropriate, now expressed as $\mathrm{d}^{14} \mathrm{C}$ or $\mathrm{D}^{14} \mathrm{C}$.

\section{ACKNOWLEDGMENTS}

Since 1975 the Radiocarbon Laboratory has functioned as a Natural Environment Research Council central facility linked to the NERC Scientific Services Division. The support and encouragement of Prof H W Wilson and the staff of the Scottish Universities Research and Reactor Centre has remained as an essential contribution to the work of the Laboratory. Excellent technical assistance with ${ }^{14} \mathrm{C}$ and associated analyses was provided by B F Miller, Elizabeth Hobson, and Ronald Spence.

The time and expertise given by the Laboratory Steering Committee to the overall research program since 1975 is gratefully acknowledged; likewise, the collaboration of the many individual users of the dating service who have provided information essential to the compilation of this date list.

\section{SAMPLE DESCRIPTIONS}

\section{A. Antarctica}

\section{Samuel Islands series, South Georgia}

Stratified Acaena magellanica and bryophyte peat in series of rejuvenated river terraces, exposed by stream erosion, in fluvio-glacial outwash fan $1 \mathrm{~km} \mathrm{~N}$ of Samuel Is., N W South Georgia (54 $\left.11^{\prime} \mathrm{S}, 37^{\circ} 37^{\prime} \mathrm{W}\right)$. Coll 1973 by R A S Clayton and subm by R I L Smith, British Antarctic Survey.

SRR-731. Samuel Is. 1

$1940 \pm 90$

Base of band ca $20 \mathrm{~cm}$ thick overlying terrace, $1.5 \mathrm{~m}$ above river.

SRR-732. Samuel Is. 2

$4760 \pm 300$

Top of band $20 \mathrm{~cm}$ thick underlying $1.5 \mathrm{~m}$ river terrace.

$$
\delta^{13} \mathrm{C}=-28.4 \%
$$


SRR-733. Samuel Is. 3

$$
1450 \pm 60
$$

70) above river.

SRR-734. Samuel Is. 4

$\mathbf{3 2 1 0} \pm \mathbf{5 0}$

Mid-depth in band $70 \mathrm{~cm}$ thick between $3 \mathrm{~m}$ and $4 \mathrm{~m}$ terraces.

\section{SRR-735. Samuel Is. 5}

$$
3890 \pm 60
$$

Top of band $70 \mathrm{~cm}$ thick between $3 \mathrm{~m}$ and $4 \mathrm{~m}$ terraces.

General Comment (RASC/RILS): according to these age estimates, peat at top of $70 \mathrm{~cm}$-thick band between $3 \mathrm{~m}$ and $4 \mathrm{~m}$ terraces is much older than material from base. Similarly, peat at top of $20 \mathrm{~cm}$-thick band underlying $1.5 \mathrm{~m}$ terrace has given much older age than peat from base of sec. Since secs were clean and free from slump structures, discrepancies are probably products of sampling technique and should not, therefore, be used to date recent glacial events.

\section{Signy Island series, South Orkney Islands}

Moss and lichen from various locations assoc with recent ice retreat, Signy I., South Orkney Is. $\left(60^{\circ} 40^{\prime} \mathrm{S}, 45^{\circ} 40^{\prime} \mathrm{W}\right)$. Map refs as quoted for individual sample collns relate to sheet DOS 210 (Signy I. $1 \mathrm{~km}$ grid). Material dated had been re-exposed during summer $1974 / 75$ by thaw of semi-permanent ice cover. Coll 1975 and subm by J H C Fenton, British Antarctic Survey.

SRR-895. Signy I. (5)

$$
\begin{array}{r}
\text { Modern } \\
\mathbf{d}^{14} \mathbf{C}=+\mathbf{4 2 . 0} \pm \mathbf{4 . 9} \% \text { \% } \\
\delta^{13} C=-24.2 \% \%
\end{array}
$$

Small carpet of Drepanocladus uncinatus on rock outcrop in McLeod Glacier (Grid Ref 1029 0435).

\section{SRR-896. Signy I. (6)}

$$
\begin{array}{r}
\text { Modern } \\
\mathbf{d}^{14} \mathbf{C}=+\mathbf{1 . 9} \pm \mathbf{6 . 5} \% \text { \% } \\
\delta^{1 s} C=-25.4 \% \text { o }
\end{array}
$$

Polytrichum juniperinum cushion on rock outcrop below Spindrift Col. This outcrop is still surrounded by permanent ice and has recently been completely buried. Some moss spp are still buried.

$$
\text { SRR-897. Signy I. (7) } \quad \mathbf{d}^{14} \mathrm{C}=\begin{array}{r}
\text { Modern } \\
\mathbf{2 0 . 5} \pm \mathbf{4 . 6} \% \\
\delta^{13} C=-24.2 \%
\end{array}
$$

Shallow bank of Chorisodontium aciphyllum turf, ca $10 \mathrm{~cm}$ deep. Lower part of bank is still buried by permanent ice although top part, ca $6 \mathrm{~m}$ from ice edge, is actively growing (Grid Ref. 1035 0438).

SRR-898. Signy I. (8)

$470 \pm 60$

$\delta^{13} C=-27.0 \%$

Extensive bank of Chorisodontium aciphyllum turf with some Polytrichum alpestre present, ca 15 to $20 \mathrm{~cm}$ deep. Surface is actively growing 
although lower $10 \mathrm{~m}$ of bank has been killed. Sample is from lower edge of bank, Im vertically above present permanent ice surface (Grid Ref $10390435)$.

\section{SRR-899. Signy I. (9)}

Modern

$$
\begin{array}{r}
\mathbf{d}^{14} \mathbf{C}=+\mathbf{2 4 . 5} \pm \mathbf{5 . 5} \% \text { o } \\
\delta^{13} C=-25.0 \% \text { o }
\end{array}
$$

Sample (pure Chorisodontium aciphyllum) ca 10 to $15 \mathrm{~cm}$ deep, on level ground (Grid Ref 1037 0435) from largest area of re-exposed moss on Signy I. with very little moss now remaining buried by permanent ice.

\section{SRR-900. Signy I. (10)}

$$
\mathbf{d}^{14} \mathbf{C}=\begin{array}{r}
\text { Modern } \\
-\mathbf{1 3 . 4} \pm \mathbf{6 . 5} \% \\
\boldsymbol{\delta}^{13} \mathrm{C}=-25.8 \%
\end{array}
$$

Lichen (Usnea antarctica) from same outcrop in McLeod Glacier as SRR-895 (Grid Ref 1029 0435).

SRR-901. Signy I. (11)

$$
\begin{array}{r}
\text { Modern } \\
\mathrm{d}^{14} \mathrm{C}=+\mathbf{6 . 9} \pm \mathbf{4 . 3} \% \\
\delta^{18} \mathrm{C}=-23.7 \%
\end{array}
$$

Permanent ice edge is now $2 \mathrm{~m}$ from this bank of Chorisodontium aciphyllum turf, 10 to $15 \mathrm{~cm}$ deep at lower end. Lower half of bank has been killed due to former cover of ice (Grid Ref 1015 0423).

General Comment (JHCF): there are now 13 dates for re-exposed moss from Signy I. and nearby Coronation I.: AD 1450 to 1500 - l sample, AD 1680 to $1715-1$ sample, AD 1750 to $1900-7$ samples, post AD $1950-4$ samples. AD 1750 to 1900 samples can perhaps be subdivided into ca AD 1770 to 1780 -4 samples, ca AD 1840 to 1880 -3 samples. Samples from similar locations have widely differing dates; thus, tentatively, we can conclude that there has been a complex pattern of snow advance and retreat during the last $500 \mathrm{yr}$, perhaps not unexpected in such a maritime climate. These dates will have to be correlated with other evidence for past climatic changes.

\section{SRR-902. Shingle Cove, Coronation Island}

$$
\mathrm{d}^{14} \mathrm{C}=\begin{array}{r}
\text { Modern } \\
-23.2 \pm 4.9 \% \\
\delta^{13} C=-26.1 \% o
\end{array}
$$

Polytrichum alpestre and Chorisodontium aciphyllum in turf bank ca $20 \mathrm{~cm}$ deep and re-exposed by overlying ice retreat halfway up $\mathrm{S}$ side of col $0.5 \mathrm{~km}$ W of Shingle Cove, Coronation I., South Orkney Is. $\left(60^{\circ} 38^{\prime}\right.$ S, $45^{\circ} 35^{\prime} \mathrm{W}$ ). Coll 1975 and subm by J H C Fenton. Comment (JHCF): date is very similar to another date obtained for re-exposed moss on Coronation I. (nearby at Cape Hansen) $168 \pm 60 \mathrm{yr}$ BP; it is also similar to many of those from Signy I.

\section{SRR-1086. Byers Peninsula, Livingston Island}

$$
\begin{array}{r}
\mathbf{2 8 2 0} \pm \mathbf{4 0} \\
\delta^{1 s} C=-20.9 \% \text { o }
\end{array}
$$

Collagen isolated from fragment taken from whalebone vertebra embedded in shingle ridge crest of ' $10 \mathrm{~m}$ ' raised beach, Byers Peninsula, South Shetland Is. $\left(62^{\circ} 38^{\prime} \mathrm{S}, 61^{\circ} \mathrm{W}\right)$. Coll 1976 and subm by J D Han- 
som, Univ Aberdeen. Comment (JDH): date fits sequence of deglaciation thought to exist in area. Correction factor of ca $750 \mathrm{yr}$ subtracted for ${ }^{14} \mathrm{C}$ deficiency in Antarctic water (Broecker and Olsen, 1961) yields date ca $2100 \mathrm{yr}$ BP and places beach age firmly between ' $6 \mathrm{~m}$ ' beach at ca $700 \mathrm{yr}$ BP and ' $18.5 \mathrm{~m}$ ' beach at ca $9000 \mathrm{yr}$ BP (Sugden and John, 1973). This beach may be assoc with re-advance dates from South America due to its age and marked prominence in series of raised beach levels.

SRR-1087. Byers Peninsula, Livingston Island

$$
3130 \pm 40
$$

$\delta^{13} C=-21.4 \%$

Collagen isolated from whalebone embedded in shingle ridge crest of ' $10 \mathrm{~m}$ ' beach, some $200 \mathrm{~m}$ from SRR-1086 $\left(62^{\circ} 38^{\prime} \mathrm{S}, 61^{\circ} \mathrm{W}\right)$. Coll 1976 and subm by J D Hansom. Comment (JDH): agreement of this date with SRR-1086 for same beach level strengthens validity of both, being taken from different sites and bone remains. However, whether beach ridge represents anything more than part of continually uplifting sequence (ie, minor re-advance), cannot be determined until morphologic evidence is found relating morainic limits to beach.

\section{Spindrift series, South Orkney Islands}

Moss peat (Chorisodontium aciphyllum) in wedge-shaped bank (ca $7 \mathrm{~m}$ wide and $2 \mathrm{~m}$ deep at vertical front face) overlying bedrock at Spindrift, Signy I. $\left(60^{\circ} 41^{\prime}\right.$ S, $45^{\circ} 38^{\prime}$ W). Coll 1976 and subm by J H C Fenton.

\section{SRR-1088. Spindrift (No. 13)}

$3380 \pm 100$

Sample from base of bank (ca $2 \mathrm{~m}$ depth) at ca $2.5 \mathrm{~m}$ in from front face.

SRR-1089. Spindrift (No. 14)

$4800 \pm 300$

Sample from base of bank (ca $1.25 \mathrm{~m}$ depth) at ca $5 \mathrm{~m}$ in from front face.

SRR-1090. Spindrift (No. 15)

Sample from base of front face (ca $2 \mathrm{~m}$ depth).

$1210 \pm 40$

$\delta^{13} C=-23.8 \%$

SRR-1091. Spindrift (No. 16)

$1150 \pm 40$

Sample from front base (ca $1.95 \mathrm{~m}$ depth).

$\delta^{13} C=-23.5 \%$

SRR-1092. Spindrift (No. 17)

$1050 \pm 40$

Sample from front face (ca $1.6 \mathrm{~m}$ depth).

$\delta^{13} C=-22.7 \%$

SRR-1093. Spindrift (No. 18)

$$
\delta^{13} C \stackrel{480}{\mathbf{4}}=-22.20
$$

Sample from front face (ca $1.3 \mathrm{~m}$ depth).

SRR-1094. Spindrift (No. 19)

$$
430 \pm 40
$$

Sample from ceiling of overhang ca $1 \mathrm{~m}$ deep in base of moss bank. 
SRR-1095. Spindrift (No. 20)

Sample from below vertical edge of moss bank.

General Comment (JHCF): earliest date here is $3000 \mathrm{yr}$ older than any previously obtained from Signy I. and gives new insight into moss bank development and vegetational history of island. Date also suggests that NW part of this small island has been ice-free for at least $5000 \mathrm{yr}$ despite proximity and possible extension of existing ice cap barely $1.5 \mathrm{~km}$ to $\mathrm{S}$. This indicates remarkably stable ice conditions and, therefore, presumably stable climatic conditions during past five millennia.

The fact that deepest peat of moss bank is not the oldest, together with dates of samples from throughout bank, provide valuable clues about formation of these moss banks.

\section{B. Atlantic Ocean}

Northwest African Shelf series

Organic detritus in marine sediment (green/gray class) coll by gravity corer from continental shelf off Cape Blanc, NW Africa $\left(20^{\circ} 46^{\prime}\right.$ $\mathrm{N}, 18^{\circ} 2^{\prime} \mathrm{W}$ ). Quoted depth intervals (in $\mathrm{cm}$ ) relate to present sea bed surface overlain by $1210 \mathrm{~m}$ water column. Coll 1972 and subm by R J Morris, Natl Inst Oceanog. HCl.

Prior to ${ }^{14} \mathrm{C}$ assay all carbonate was removed by digestion in $0.5 \mathrm{~m}$

SRR-554. N WAfrican shelf, 13 to $15 \mathrm{~cm}$

SRR-555. N W African shelf, 27 to $30 \mathrm{~cm}$

SRR-556. N W African shelf, 42 to $45 \mathrm{~cm}$

SRR-557. N W African shelf, 56 to $60 \mathrm{~cm}$

SRR-558. N W African shelf, 68 to $73 \mathrm{~cm}$ $\mathbf{3 0 4 0} \pm \mathbf{2 6 0}$

$\delta^{13} C=-21.8 \%$ o

$\mathbf{5 1 4 0} \pm \mathbf{3 0 0}$

$\delta^{1 s} C=-20.9 \%$

$1730 \pm 290$

$\delta^{13} C=-17.7 \%$ o

$6530 \pm 230$ $\delta^{13} C=-21.7 \%$

$10,420 \pm 370$

$\delta^{13} \mathrm{C}=-22.9 \%$

General Comment (RJM): SRR-556 is considered anomalous. Significance of ages in relation to other geochemical analyses discussed in Gaskell et al (1975).

\section{Azores series, Atlantic Ocean}

Finely divided carbonate in marine sediment coll by gravity corer from Atlantic abyssal plain $\left(38^{\circ} 21^{\prime} \mathrm{N}, 22^{\circ} 37^{\prime} \mathrm{W}\right)$. Quoted depth intervals (in $\mathrm{cm}$ ) relate to present sea bed surface overlain by $4000 \mathrm{~m}$ water column. Coll 1974 and subm by R J Morris.

SRR-559. Azores, (A2), 17 to $34 \mathrm{~cm}$

$12,680 \pm 250$

$\delta^{13} \mathrm{C}=-0.3 \%$ 
SRR-560. Azores, (A3), 34 to $51 \mathrm{~cm}$

$28,100 \pm 190$

SRR-561. Azores, (A4), 51 to $68 \mathrm{~cm}$

$\delta^{1 s} C=-0.2 \%$

$\mathbf{3 4 , 2 8 0} \pm \mathbf{4 5 0}$

$\delta^{13} C=+0.1 \%$ o

General Comment (RJM): as expected, ages show very slow accumulation rate for this abyssal plain sediment. There is no evidence of large scale slumping or sliding or contribution from turbidity currents during sedimentary period of this core.

\section{Southwest African shelf series}

Organic detritus in marine sediment (dark green diatomaceous ooze) coll by gravity corer from continental shelf just off Walvis Bay, SW Africa $\left(22^{\circ} 56^{\prime} \mathrm{S}, 14^{\circ} 0^{\prime} \mathrm{E}\right)$. Quoted depth intervals (in $\mathrm{cm}$ ) relate to present sea bed surface overlain by $143 \mathrm{~m}$ water column. Coll 1968 by S E Calvert subm by R J Morris. HCl.

Prior to ${ }^{14} \mathrm{C}$ assay all carbonate was removed by digestion in $0.5 \mathrm{~m}$

SRR-562. S W African shelf, 15 to $20 \mathrm{~cm}$

\section{SRR-563. S W African shelf, 35 to $40 \mathrm{~cm}$}

SRR-564. S W African shelf, 55 to $60 \mathrm{~cm}$

$$
\begin{array}{r}
\mathbf{4 8 0} \pm \mathbf{1 0 0} \\
\delta^{1 s} C=-19.5 \% 0 \\
\mathbf{9 8 0} \pm \mathbf{1 8 0} \\
\delta^{1 s} C=-20.5 \% \\
\mathbf{9 4 0} \pm \mathbf{6 0} \\
\delta^{1 s} C=-19.6 \% o
\end{array}
$$

General Comment (RJM): ages confirm very rapid accumulation rate for this extremely organic-rich sediment underlying ocean area of high productivity. The $\delta^{13} \mathrm{C}$ data indicate that inputs to these sediments are predominantly marine with little terrigenous contribution (Morris and Calvert, 1977; Calvert and Morris, 1977).

\section{Walvis Bay series, Southwest Africa}

Organic detritus in marine sediment (rich diatomaceous ooze) coll by gravity corer in Walvis Bay. Four cores taken at different locations viz, Core A $\left(21^{\circ} 15^{\prime} \mathrm{S}, 13^{\circ} 40^{\prime} \mathrm{E}\right)$, Core B $\left(22^{\circ} 51^{\prime} \mathrm{S}, 14^{\circ} 29^{\prime} \mathrm{E}\right)$, Core C $\left(23^{\circ} 4^{\prime} \mathrm{S}, 12^{\circ} 59^{\prime} \mathrm{E}\right)$, Core D $\left(21^{\circ} 55^{\prime} \mathrm{S}, 12^{\circ} 35^{\prime} \mathrm{E}\right)$. Quoted sample depth increments (in $\mathrm{cm}$ ) relate to sea bed surface. Coll 1975 and subm by $\mathrm{R} J$ Morris.

Prior to ${ }^{14} \mathrm{C}$ assay all carbonate removed by digestion of sediment in $0.5 \mathrm{~m} \mathrm{HCl}$.

SRR-794. Walvis Bay, (Core A), 0 to $7 \mathrm{~cm}$

SRR-795. Walvis Bay, (Core A), 27 to $30 \mathrm{~cm}$

SRR-796. Walvis Bay, (Core A), 57 to $60 \mathrm{~cm}$

$$
\begin{array}{r}
\mathbf{6 7 0} \pm \mathbf{8 0} \\
\delta^{15} C=-20.5 \% \\
\mathbf{1 1 3 0} \pm \mathbf{5 0} \\
\delta^{15} C=-20.3 \% \\
\mathbf{2 1 4 0} \pm \mathbf{8 0} \\
\delta^{13} C=-20.1 \%
\end{array}
$$


$\mathbf{2 9 7 0 \pm 6 0}$

SRR-797. Walvis Bay, (Core A), 82 to $85 \mathrm{~cm} \quad \delta^{13} C=-21.0 \%$ o SRR-798. Walvis Bay, (Core B), 0 to $7 \mathrm{~cm} \quad \begin{array}{r}970 \pm 180 \\ \delta^{13} C=-20.6 \%\end{array}$

$1530 \pm 140$

SRR-799. Walvis Bay, (Core B), 73 to $76 \mathrm{~cm}$ $\delta^{13} C=-20.5 \%$

SRR-800. Walvis Bay, (Core $\mathrm{C}), 0$ to $6 \mathrm{~cm}$

$2410 \pm 100$ $\delta^{13} C=-20.4 \%$

$13,160 \pm 190$

SRR-801. Walvis Bay, (Core C), 45 to $48 \mathrm{~cm}$ $\delta^{13} C=-24.8 \%$

SRR-802. Walvis Bay, (Core D), 0 to $6 \mathrm{~cm}$

$$
3430 \pm 60
$$
$\delta^{13} C=-20.8 \%$

$9670 \pm 100$

SRR-803. Walvis Bay, (Core D), 45 to $48 \mathrm{~cm} \quad \delta^{1 s} C=-20.9 \%$ o General Comment (RJM): ages confirm high sedimentation rate and predominance of marine input for S W African shelf series. Cores appear to be in original time sequence of deposition and do not appear to have been remobilized or redeposited on a large scale (Wardroper, Maxwell, and Morris, 1978).

\section{Northwest African continental slope series}

Marine sediment coll by gravity coring at two locations on continental slope off N W Africa viz, Discovery Sta $8534\left(13^{\circ} 19^{\prime} \mathrm{N}, 20^{\circ} 40^{\prime}\right.$ $\mathrm{W})$ and Discovery Sta $8539\left(10^{\circ} 55^{\prime} \mathrm{N}, 19^{\circ} 32^{\prime} \mathrm{W}\right)$. Quoted sample depth increments (in $\mathrm{cm}$ ) relate to present sea floor. Coll 1974 and subm by $\mathrm{S}$ Calvert, Inst Oceanog Sci.

Where recovered in sufficient amount both carbonate (inorganic) and acid resistant (organic) fractions were analyzed for each sample. Carbonate $\mathrm{CO}_{2}$ was initially evolved $\left(50 \% \mathrm{H}_{3} \mathrm{PO}_{4}\right)$ by acid hydrolysis. Organic carbon was subsequently recovered as $\mathrm{CO}_{2}$ via chromic acid oxidation.

SRR-1034. Sta 8534, 0 to $10 \mathrm{~cm}$

$$
\begin{array}{lr}
\text { (a) inorganic } & \mathbf{4 6 8 0} \pm \mathbf{5 0} \\
& \delta^{13} C=+0.5 \% \\
\text { (b) organic } & \mathbf{4 8 2 0} \pm \mathbf{1 5 0}
\end{array}
$$

SRR-1035. Sta 8534, 32 to $40 \mathrm{~cm}$

inorganic

SRR-1036. Sta 8534, 55 to $62 \mathrm{~cm}$

$$
\text { (a) inorganic }
$$

$12,330 \pm 140$ $\delta^{13} C=-0.7 \%$

$15,210 \pm 290$ $\delta^{13} C=-0.2 \%$ o 
(a) inorganic

(b) organic

SRR-1038. Sta 8539, 0 to $9 \mathrm{~cm}$ (b) organic

SRR-1037. Sta 8534, 108 to $117 \mathrm{~cm}$

16,820

$+570$ $-\mathbf{5 4 0}$

$\delta^{13} C=-19.8 \%$

$$
\begin{array}{rr}
29,170 & +670 \\
-620 \\
\delta^{1 s} C= & -0.2 \% \\
& +680 \\
16,090 & -630 \\
\delta^{1 s} C=-20.5 \%
\end{array}
$$

$$
\begin{array}{r}
\mathbf{4 5 7 0} \pm \mathbf{5 0} \\
\delta^{13} C=+0.7 \% o
\end{array}
$$

$15,160 \pm 260$ $\delta^{13} C=-17.6 \%$

SRR-1040. Sta 8539, 101 to $102 \mathrm{~cm}$

organic

$$
\begin{gathered}
14,670+380 \\
\delta^{1 s} C=-17.6 \%
\end{gathered}
$$

General Comment (SEC): both cores consist of upper oxidized (redbrown) horizon overlying reduced (gray-green) horizon with boundary occurring between SRR-1035 and -1036 and immediately above -1039. This change in sediment type may reflect break in sedimentation rate, upper horizon being more highly oxidized because of much lower rate. 'Organic' ages for Core 8534 confirm this interpretation, and those for Core 8539 are consistent with it.

It is inferred that during latter part of Pleistocene, when sea level was much lower than at present, rate of sedimentation was very rapid and that this sediment contained old carbonate derived from shelf or upper slope areas. Marked discrepancy between ages obtained for two component fractions in SRR-1037 may well result from this resedimentation of old biogenic carbonate.

\section{Fox Earth Gill series}

$$
\text { C. England }
$$

Peat and detritus mud in monolith coll from peat haggs adjacent to Fox Earth Gill, Upper Teesdale, Yorkshire (54 $34^{\circ} \mathrm{N}, 2^{\circ} 15^{\prime} \mathrm{W}$, Natl Grid Ref NY 842 282). Quoted sample depths (in $\mathrm{cm}$ ) relate to ground surface. Coll 1971 and subm by R H Squires, Univ Minnesota.

Prior to ${ }^{14} \mathrm{C}$ assay all samples were digested in $\mathrm{HCl}$ to remove possible calcareous contamination from limestone outcrops in region. 
SRR-397. Fox Earth Gill, 105em

Carex peat corresponds to start of elm decline.

SRR-398. Fox Earth Gill, 120cm

Carex peat corresponds to end of oak-pine assemblage zone and siart of oak-alder assemblage zone. End of substantial sedge curve fluctuations.

\section{SRR-399. Fox Earth Gill, 200cm}

Carex peat corresponds to end of birch-hazel assemblage zone.

$7310 \pm 69$ $\delta^{13} \mathrm{C}=-28.2 \%$

SRR-400. Fox Earth Gill, 234cm

$\delta^{13} C=-28.8 \%$

Coarse detritus mud corresponds to end of mud accumulation and onset of fen conditions. Start of pine-elm subzone of birch-hazel assemblage zone.

\section{SRR-401. Fox Earth Gill, 246cm}

$$
8130 \pm 60
$$$$
\delta^{13} C=-29.5 \%
$$

Detritus mud corresponds to initiation of organic deposition.

General Comment (RHS): ages are complementary to those pub by Turner et al (1973).

\section{Hallowell Moss series}

Peat and organic mud in core from center of Halloweil Moss, a small raised bog, Browney Valley, Durham (54 $47^{\prime} \mathrm{N}, 1^{\circ} 37^{\prime} \mathrm{W}$, Natl Grid Ref NZ24 252441). Quoted sample depths (in $\mathrm{cm}$ ) relate to ground surface. Coll 1973 and subm by J Turner, Univ Durham.

\section{SRR-411. Hallowell Moss 1, 50em}

$$
910 \div 60
$$$$
\delta^{13} \mathrm{C}=-28.4 \%
$$

Sphagnum-Eriophorum relates to upper part of pollen diagram after first major clearance.

SRR-412. Hallowell Moss 2, 71cm

$$
1520 \pm 70
$$

$\delta^{13} \mathrm{C}=-28.3 \%$

Muddy Eriophorum relates to start of regeneration of trees after major forest clearance for pasture and cultivation.

\section{SRR-413. Hallowell Moss 3, 73cm}

$$
\mathbf{1 3 6 0} \pm \mathbf{5 0}
$$

Muddy Eriophorum relates to end of major clearance phase I ast sample with high percentages of grass pollen.

\section{SRR-A14. Hallowell Moss 4, 80cm}

$1780 \pm 60$

Muddy Eriophorum relates to first major clearance. 
SRR-4.15. Hallowell Moss 5, $90 \mathrm{~cm}$

$1960 \pm 70$

Muddy Eriophorum relates to start of a major clearance phase, shown by rise in grass pollen.

SRR-416. Hallowell Moss $6,133 \mathrm{~cm}$

$2230 \pm 80$

$\delta^{13} C=-29.2 \%$

Woody Eriophorum relates to period before first major clearance when tree pollen percentage still high.

\section{SRR-417. Hallowell Moss 7, 153cm}

Unhumified Eniophorum containing higher percentage of grass pollen than adjacent levels. May indicate small temporary clearance.

Organic mud relates to period in which a light rise in grass pollen was soon followed by rise in shrub pollen, decrease in Tilia and appearance of Plantago lanceolata, indicating gradual slight opening out of forest perhaps for grazing.

\section{SRR-419. Hallowell Moss 9, 279 to $281 \mathrm{~cm}$}

$$
4940 \pm 60
$$

Organic mud relates to first entirely organic deposit at lower end of pollen diagram and contains very high levels of tree pollen.

General Comment (JT): dates, assoc with detailed pollen diagram from moss, indicate that area was wooded until Romano-British times when it was deforested, and cleared land used for both arable and pastoral farming (SRR-414,-415). In 6th century AD (SRR-413), when Anglo-Saxons arrived in area, farming appears to have ceased and the land to have reverted to woodland. Nothing much changed until after 1lth century (SRR-411), probably not until the 16th and 17 th centuries when woods were once again cleared.

\section{Blelham Tarn series}

Organic lake mud (fine detritus gyttja) from Blelham Tarn $\left(54^{\circ} 23^{\prime}\right.$ N, $2^{\circ} 58^{\prime} \mathrm{W}$, Natl Grid Ref NY 365005 ). Core 74/D (SRR-454 to -457 ) coll using $1 \mathrm{~m}$ Mackereth minicorer from same location as previously reported Core 73/1 (R, v 21, p 218 to 219), SRR-458 is from Core 73/1. Quoted sample depth increments (in $\mathrm{cm}$ ) relate to $\mathrm{mud} /$ water interface. Coll 1974 and subm by W Tutin, Univ Leicester.

\begin{tabular}{|c|c|c|}
\hline SRR-456. & Blelham Tarn, 50 to $55 \mathrm{~cm}$ & $\begin{array}{r}\mathbf{9 0 0} \pm \mathbf{8 0} \\
\delta^{1 s} C=-28.9 \%\end{array}$ \\
\hline SRR-457. & Blelham Tarn, 55 to $60 \mathrm{~cm}$ & $\begin{array}{r}\mathbf{8 5 0} \pm \mathbf{8 0} \\
\delta^{18} C=-28.7 \% 0\end{array}$ \\
\hline $\mathrm{SPR}-458$. & Bleham Tarn, 55 to $65 \mathrm{~cm}$ & $\begin{array}{r}\mathbf{9 8 0} \pm \mathbf{8 0} \\
\delta^{1 s} C=-29.1 \% 0\end{array}$ \\
\hline
\end{tabular}


SRR-454. Blelham Tarn, 65 to $75 \mathrm{~cm}$

SRR-455. Blelham Tarn, 80 to $90 \mathrm{~cm}$ $\mathbf{5 2 0} \pm \mathbf{4 5 0}$

$\delta^{13} C=-28.8 \%$

$\mathbf{8 0 0} \pm \mathbf{5 0}$

$\delta^{13} C=-28.8 \%$

\section{Core B series}

Lake mud (fine detritus gytjja) in Core B coll from position of max rate of sediment accumulation as determined by Cs-137 and $\mathrm{Pb}-210$ dating. Palaeomagnetic measurements indicate AD 1820 horizon at ca $60 \mathrm{~cm}$ depth.

SRR-544. Blelham Tarn B, 70 to $75 \mathrm{~cm}$

SRR-545. Blelham Tarn B, 75 to $85 \mathrm{~cm}$

SRR-546. Blelham Tarn B, 85 to $90 \mathrm{~cm}$

SRR-547. Blelham Tarn B, 90 to $95 \mathrm{~cm}$

$$
\begin{array}{r}
\mathbf{8 6 0} \pm \mathbf{7 0} \\
\delta^{13} C=-28.8 \% \\
\mathbf{1 0 3 0} \pm \mathbf{6 0} \\
\delta^{13} C=-28.8 \% \\
\mathbf{7 7 0} \pm \mathbf{6 0} \\
\delta^{13} C=-29.6 \% \\
\mathbf{7 9 0} \pm \mathbf{6 0} \\
\delta^{1 s} C=-29.5 \%
\end{array}
$$

General Comment (WT): when correlated with analyses for pollen and sediment composition these ages, from different positions in lake, show that sediments immediately below horizon dated to AD 1820 by palaeomagnetic measurements contain carbon that is much older than time of deposition in lake, and that ${ }^{14} \mathrm{C}$ ages of contiguous samples do not form ordered sequence. This is explained by hypothesis that agricultural practices (deforestation and ploughing) have had a profound effect in disturbing orderly transfer to lake sediments of material eroded from catchment (Pennington et al, 1976).

\section{Gale Bog series}

Sphagnum sp from decaying peat bog overlying glacial drift on edge of eutrophic lake (Rostherne Mere), Gale Bog, Rostherne, Cheshire (53 $22^{\prime}$ N, $2^{\circ} 23^{\prime}$ W, Natl Grid Ref SJ 740 847). Quoted sample depth increments (in cm) relate to bog surface. Coll 1974 and subm by D A Rogers, Nature Conservancy.

SRR-461. Gale Bog, 10 to $40 \mathrm{~cm}$

$$
\begin{array}{r}
\text { Modern } \\
\mathbf{d}^{14} \mathbf{C}=-\mathbf{2 7 . 3} \pm \mathbf{8 . 5} \% \\
\delta^{1 s} C=-28.2 \% \\
\mathbf{6 6 0} \pm \mathbf{8 0} \\
\delta^{1 s} C=-26.8 \% \\
\mathbf{3 7 0 0} \pm \mathbf{7 0} \\
\delta^{1 s} C=-28.5 \%
\end{array}
$$

SRR-462. Gale Bog, 70 to $100 \mathrm{~cm}$

SRR-463. Gale Bog, 670 to $700 \mathrm{~cm}$

General Comment (DAR): dates give reasonably constant rate of peat accumulation of ca $20 \mathrm{~cm} /$ century. This is quite rapid-ca twice mean value for most British sites. 


\section{Dufton Moss series}

Carex peat coll using piston corer from Dufton Moss, Upper Teesdale, Co Durham (54 $40^{\prime} \mathrm{N}, 2^{\circ} 2^{\prime} \mathrm{W}$, Natl Grid Ref NY 872 293). Quoted depths (in $\mathrm{cm}$ ) relate to present ground surface. Coll 1971 and subm by $\mathrm{R} H$ Squires.

Prior to ${ }^{14} \mathrm{C}$ assay all samples were digested in $\mathrm{HCl}$ to remove possible calcareous inclusions from dolerite outcrops in region.

SRR-508. Dufton Moss, $120 \mathrm{~cm}$

Dates secondary elm decline.

SRR-509. Dufton Moss, $245 \mathrm{~cm}$

Dates end of primary elm decline.

SRR-510. Dufton Moss, $280 \mathrm{~cm}$

Dates start of primary elm decline.

SRR-511. Dufton Moss, $335 \mathrm{~cm}$

Dates end of Pine assemblage zone. $\mathbf{3 6 8 0} \pm \mathbf{8 0}$

$\delta^{13} \mathrm{C}=-27.4 \%$

$4560 \pm 60$

$\delta^{13} C=-28.0 \%$

$5360 \pm 70$

$\delta^{13} \mathrm{C}=-27.7 \%$

$\mathbf{5 7 0 0} \pm \mathbf{5 0}$
$\delta^{13} \mathrm{C}=-26.8 \%$

General Comment (RHS): data compare with other radiocarbon ages from Upper Teesdale; SRR-88 to -95 (Upper Valley Bog), SRR-107 to -108, and GaK-2913 to -2919 (Weelhead Moss), SRR-397 to -401 (Fox Earth Gill), and GaK-2027 to -2031 (Red Sike Moss).

\section{Williamsons' Moss series}

Fine detritus gyttja from bed of peat in filled shallow lake, Williamsons' Moss, Eskmeals, Cumbria $\left(54^{\circ} 19^{\prime} \mathrm{N}, 3^{\circ} 25^{\prime} \mathrm{W}\right.$, Natl Grid Ref SD 083920 ). Lake sediments overlain by ca $1 \mathrm{~m}$ peat accumulation. Samples coll at quoted depths (in $\mathrm{cm}$ ) below present peat surface using Hiller borer. Coll 1974 and subm by W Tutin.

SRR-565. Williamsons' Moss, 210 to $214 \mathrm{~cm}$ $3860 \pm 60$
$\delta^{1 s} C=-31.2 \%$

SRR-566. Williamsons' Moss, 214 to $218 \mathrm{~cm}$ $\mathbf{3 9 2 0} \pm \mathbf{5 0}$

SRR-567. Williamsons' Moss, 220 to $225 \mathrm{~cm}$ $\delta^{13} C=-31.0 \%$ $\mathbf{4 3 4 0} \pm 50$

SRR-568. Williamsons' Moss, 225 to $230 \mathrm{~cm}$ $\delta^{13} \mathrm{C}=-30.7 \%$

$$
4610 \pm 60
$$
$\delta^{13} C=-30.7 \%$

SRR-569. Williamsons' Moss, 230 to $235 \mathrm{~cm}$ $4020 \pm 50$

SRR-570. Williamsons' Moss, 235 to $240 \mathrm{~cm} \quad \delta^{13} C=-30.0 \%$ o General Comment (WT): samples were taken with 4-inch borer from position of undated pub percentage pollen diagram (Pennington, 1975a) 
with object of preparing an absolute pollen diagram. Samples span deposits from well below elm decline at ca $5000 \mathrm{BP}$, and are unacceptably young as well as forming disordered sequence. Thus, downward penetration of humus has occurred at this site, which has yielded surface Neolithic finds, and is unsuitable for dating organic deposits.

\section{SRR-532. Trench Wood}

$4480 \pm 50$

Cellulose fraction of wood fragment from trial pit (T 15/2) dug in terrace-like feature below Trench Wood on left bank of Aire $\mathrm{R}$ valley, near Shipley, Yorkshire (53 $50^{\prime} \mathrm{N}, 1^{\circ} 37^{\prime} \mathrm{W}$, Natl Grid Ref SE 136 386). Wood at base of horizon of gray medium sand at ca 1.14 to $1.56 \mathrm{~m}$ depth below present ground level at $74.96 \mathrm{~m}$ OD. Coll 1974 and subm by $\mathrm{J} N$ Hutchinson, Imperial Coll London.

\section{SRR-533. Holme House Wood}

$$
\begin{array}{r}
\text { Modern } \\
\mathbf{d}^{14} \mathrm{C}=-\mathbf{2 8 . 4} \pm \mathbf{4 . 6} \% \text { o }
\end{array}
$$

Cellulose fraction of wood fragment from trial pit (T28) on S flank of the ancient Holme House Wood landslip in Aire $\mathrm{R}$ valley, near Bingley, Yorkshire $\left(53^{\circ} 50^{\prime} \mathrm{N}, 1^{\circ} 50^{\prime} \mathrm{W}\right.$, Natl Grid Ref SE 114 389). Wood in horizon of light blue/gray clay at ca 1.2 to $1.25 \mathrm{~m}$ depth below present ground level at $79.8 \mathrm{~m}$ OD. Coll 1974 by R Dowell subm by J N Hutchinson.

\section{SRR-598. Mucking Flats}

$$
5300 \pm 50
$$

$\delta^{19} \mathrm{C}=-28.9 \%$

Peat from band ca $1 \mathrm{~m}$ thick overlain by $6 \mathrm{~m}$ very soft alluvial clay, Mucking Flats, Essex ( $51^{\circ} 30^{\prime} \mathrm{N}, 0^{\circ} 27^{\prime} \mathrm{E}$, Natl Grid Ref TQ 699 809). Coll 1975 and subm by R S Pugh, Imperial Coll London. Comment (RSP): age used to estimate previous sea levels.

\section{East Midlands Triassic aquifer series, England}

Groundwaters, sampled at various pumping locations, from major Triassic sandstone aquifer of Lincoln/Worksop region $\left(53^{\circ} 20^{\prime} \mathrm{N}, 1^{\circ} \mathrm{W}\right)$. Coll 1975 and subm by M W Edmunds and A H Bath, Inst Geol Sci, Wallingford.

With exception of SRR-649 and -650, samples for $\mathrm{d}^{14} \mathrm{C}$ and quoted $\delta^{13} \mathrm{C}$ measurements were coll by precipitation as $\mathrm{BaCO}_{3}$ in the field.

SRR-602. Gainsborough No. 1 (Natl Grid Ref S8160 K8890).

SRR-603. Gainsborough, Humble Carr (Nat Grid Ref S8180 K8820).
$3970 \pm 60$ $\mathrm{d}^{14} \mathrm{C}=-\mathbf{3 9 0 . 1} \pm \mathbf{4 . 1} \%$ $\delta^{1 s} \mathrm{C}$ sample lost

$\mathrm{d}^{14} \mathrm{C}=-\mathbf{9 8 4 . 3} \pm \mathbf{1 . 7} \%$ $\delta^{1 s} C=-8.7 \%$ 


\section{SRR-604. Egmanton}

(Natl Grid Ref S7540 K6820).

SRR-605. Clarks, Retford No. 1

(Natl Grid Ref S7027 K8180).

SRR-606. Bothamsall

(Natl Grid Ref S6638 K7418).

SRR-607. Rampton Hospital

(Natl Grid Ref S7760 K7760).

SRR-608. South Scarle

(Natl Grid Ref S8558 K6505).

SRR-609. Grove No. 2

(Natl Grid Ref S7410 K8035).

SRR-610. Newton No. 2(a)

(Natl Grid Ref S8261 7425).

SRR-611. Newton No. 2(b)

(Natl Grid Ref S8261 7425).

SRR-649. Grove No. 3
$10,730 \pm 90$

$\mathbf{d}^{14} \mathbf{C}=-\mathbf{7 3 7 . 0} \pm \mathbf{2 . 8} \%$ $\delta^{13} C=-11.5 \%$

$\mathbf{3 4 5 0} \pm \mathbf{7 0}$ $\mathbf{d}^{14} \mathbf{C}=-\mathbf{3 4 9 . 5} \pm \mathbf{5 . 6} \%$
$\delta^{13} \mathrm{C}=-12.3 \%$

$\mathbf{5 8 9 0} \pm \mathbf{8 0}$

$\mathrm{d}^{14} \mathrm{C}=-\mathbf{5 1 9 . 7} \pm \mathbf{4 . 7} \%$ $\delta^{13} C=-12.9 \%$ $+1560$ $\mathbf{4 0 , 0 8 0}$

$\mathbf{d}^{14} \mathrm{C}=-\mathbf{9 9 3 . 2} \pm \mathbf{1 . 2} \%$ $\delta^{13} \mathrm{C}=-10.1 \%$

$>48,500$

$\mathbf{d}^{14} \mathbf{C}=-\mathbf{9 9 7 . 6} \pm \mathbf{1 . 2} \%$ $\delta^{13} C=-0.5 \%$

$\mathbf{1 3 , 7 8 0} \pm \mathbf{1 3 0}$
$\mathrm{d}^{14} \mathrm{C}=-\mathbf{8 2 0 . 2} \pm \mathbf{2 . 9} \%$
$\delta^{1 s} \mathrm{C}=-11.8 \% 0$

$>48,500$

$\mathbf{d}^{14} \mathrm{C}=-\mathbf{9 9 7 . 6} \pm \mathbf{1 . 2} \%$ $\delta^{13} C=-9.2 \%$ $\mathbf{3 3 , 5 8 0}$

$+1670$ $-1380$

$\mathbf{d}^{14} \mathrm{C}=-\mathbf{9 8 4 . 7} \pm \mathbf{2 . 9} \%$ $\delta^{13} \mathrm{C}=-9.2 \%$ $12,870 \pm 90$
$\mathbf{d}^{14} \mathrm{C}=-\mathbf{7 9 8 . 6} \pm \mathbf{2 . 2} \%$
$\delta^{1 s} \mathrm{C}=-13.6 \%$

Sample coll by adsorption on ion exchange column. (Natl Grid Ref S7403 K8030).

SRR-650. Grove No. 3

$$
\begin{array}{r}
\mathbf{1 3 , 0 8 0} \pm \mathbf{1 3 0} \\
\mathbf{d}^{14} \mathrm{C}=-\mathbf{8 0 3 . 7} \pm \mathbf{3 . 1} \% \\
\delta^{13} C=-11.5 \% o
\end{array}
$$

Sample coll by adsorption in $\mathrm{NaOH}$ solution.

SRR-651. Grove No. 3

$$
\begin{array}{r}
13,030 \pm 90 \\
\mathbf{d}^{14} \mathrm{C}=-\mathbf{8 0 2 . 4} \pm 2.2 \% \\
\delta^{13} C=-11.8 \%
\end{array}
$$

Sample coll as $\mathrm{CO}_{3}{ }^{2-} / \mathrm{SO}_{4}{ }^{2-}$ precipitate. 
SRR-652. Everton No. 1

(Natl Grid Ref S6915 K9020).

SRR-653. Everton No. 3

(Natl Grid Ref S6935 K9011).

SRR-654. Newark, Castle Brewery

(Natl Grid Ref S7980 K5360).

SRR-655. Clarks No. 2

(Natl Grid Ref S7027 K8189).

SRR-656. Markham Clinton No. 1 (Natl Grid Ref S7110 K7270).

SRR-657. Ordsall No. 1

(Natl Grid Ref S6955 K8016).

SRR-658. Whisker Hill

(Natl Grid Ref S6917 K8003).

SRR-659. Newark, British Gypsum (Natl Grid Ref S8120 K5420).

SRR-660. Gainsborough, Lea Rd No. 3

(Natl Grid Ref S8160 K8190).

SRR-661. B P Corringham Rd (Natl Grid Ref S832 K903).

SRR-662. Gainsborough, Lea Rd No. 2

(Natl Grid Ref S8160 K8890).
$6950 \pm 90$

$d^{14} \mathrm{C}=-\mathbf{5 7 8 . 9} \pm \mathbf{4 . 6} \%$ o $\delta^{13} C=-11.5 \%$

$6970 \pm 80$

$d^{14} C=-\mathbf{5 8 0 . 0} \pm \mathbf{4 . 1} \% o$
$\delta^{13} C=-12.4 \% o$

$\delta^{13} \mathrm{C}=-12.4 \%$

$\mathbf{3 3 , 0 5 0}$

$+850$ $-\mathbf{7 7 0}$

$\mathrm{d}^{14} \mathrm{C}=-\mathbf{9 8 3 . 7} \pm \mathbf{1 . 6} \%$ $\delta^{13} C=-8.6 \%$

$$
\mathbf{5 1 6 0} \pm \mathbf{8 0}
$$

$d^{14} \mathrm{C}=-474.2 \pm 4.9 \%$
$\delta^{13} C=-12.6 \%$ o

$\mathbf{1 0 , 6 2 0} \pm \mathbf{1 2 0}$
$\mathbf{d}^{14} \mathrm{C}=-\mathbf{7 3 3 . 3} \pm \mathbf{4 . 0} \%$ o
$\delta^{13} C=-11.0 \%$ o

$6900 \pm 120$

$d^{14} \mathbf{C}=-\mathbf{5 7 6 . 1} \pm \mathbf{6 . 1} \%$ 。 $\delta^{13} C=-11.9 \%$ 。

$7520 \pm 120$

$\mathbf{d}^{14} \mathrm{C}=-\mathbf{6 0 8 . 0} \pm \mathbf{5 . 9} \%$
$\delta^{13} C=-11.8 \%$ o

$$
29,220+650
$$

$-600$

$\mathbf{d}^{14} \mathbf{C}=-\mathbf{9 7 3 . 7} \pm \mathbf{2 . 0} \%$ o $\delta^{19} C=-8.5 \%$ o

$\mathbf{3 6 , 2 8 0}$

$$
+1750
$$

$-1440$

$\mathrm{d}^{14} \mathrm{C}=-\mathbf{9 9 1 . 4} \pm 1.7 \%$

$\delta^{13} C=-9.0 \%$

$$
28,880+1100
$$

$\mathbf{d}^{14} \mathbf{C}=-\mathbf{9 7 2 . 5} \pm \mathbf{3 . 5} \%$ $\delta^{13} C=-9.4 \%$ o

$\mathrm{d}^{14} \mathrm{C}=-\begin{array}{r}\mathbf{2 4 , 4 5 0} \pm \mathbf{2 8 0} \\ \mathbf{9 5 2 . 4} \pm \mathbf{1 . 7} \%\end{array}$ $\delta^{13} C=-9.7 \%$ 
SRR-663. B P Corringham Rd (Natl Grid Ref S832 K903).

SRR-664. Boughton

(Natl Grid Ref S6690 K6970).

\section{SRR-665. Amen Corner}

(Natl Grid Ref S6420 K6550).

SRR-702. Far Baulker No. 3 (Natl Grid Ref S6120 K5433).

\section{SRR-703. Farnsfield \\ (Natl Grid Ref S6556 K5678).}

SRR-704. Caunton

(Natl Grid Ref S7388 K6000).

SRR-705. Halam No. 1

(Natl Grid Ref S6700 K5368).

SRR-706. Ompton No. 2 (Natl Grid Ref S6771 K6483).

SRR-707. Rufford No. 4 (Natl Grid Ref S6325 K6100).

SRR-708. Elkesley No. 6 (Natl Grid Ref S6638 K7598).

SRR-709. Elkesley No. 5 (Natl Grid Ref S6638 K7598).
$>33,450$

$\mathrm{d}^{14} \mathrm{C}=-\mathbf{9 8 8 . 2} \pm \mathbf{4 . 4} \%$ $\delta^{13} C=-3.6 \%$

$4800 \pm 90$

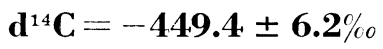
$\delta^{13} C=-12.4 \%$ o

$4490 \pm 90$

$\mathrm{d}^{14} \mathrm{C}=-\mathbf{4 2 7 . 7} \pm \mathbf{6 . 1} \%$ $\delta^{13} C=-12.6 \%$ o

$3620 \pm 70$

$\mathbf{d}^{14} \mathbf{C}=-\mathbf{3 6 2 . 6} \pm \mathbf{5 . 1} \%$ $\delta^{13} C=-13.1 \%$ o

$5970 \pm 90$

$d^{14} \mathbf{C}=-\mathbf{5 2 4 . 4} \pm \mathbf{5 . 3} \%$ $\delta^{18} C=-12.4 \%$ o

$12,580 \pm 70$

$\mathbf{d}^{14} \mathrm{C}=-\mathbf{7 9 1 . 1} \pm \mathbf{1 . 9} \%$ $\delta^{13} C=-11.2 \%$

$10,060 \pm 80$

$\mathbf{d}^{14} \mathrm{C}=-\mathbf{7 1 4 . 3} \pm \mathbf{2 . 7} \%$ $\delta^{13} C=-9.7 \%$

$\mathbf{5 5 6 0} \pm \mathbf{7 0}$ $d^{14} \mathbf{C}=-499.7 \pm 3.9 \%$ $\delta^{13} C=-12.8 \%$ o

$6940 \pm 70$

$\mathrm{d}^{14} \mathrm{C}=-\mathbf{5 7 8 . 3} \pm \mathbf{3 . 4} \%$ $\delta^{13} C=-11.6 \%$ 。

$2040 \pm 50$

$\mathrm{d}^{14} \mathrm{C}=-\mathbf{2 2 3 . 9} \pm \mathbf{4 . 2} \%$ $\delta^{13} C=-13.5 \%$ o

$2770 \pm 70$

$d^{14} \mathbf{C}=-\mathbf{2 9 1 . 5} \pm \mathbf{5 . 9} \%$ 。 $\delta^{13} C=-12.9 \%$ o

General Comment (WME): ${ }^{14} \mathrm{C}$ results have enabled development of 40,000-yr recharge history of Permo-Triassic aquifer. $d^{14} \mathrm{C}$ and $\delta^{13} \mathrm{C}$ show downgradient decrease and increase, respectively. ${ }^{14} \mathrm{C}$ data have been interpreted in terms of total carbon geochemistry. $\delta^{13} \mathrm{G}$ values demonstrate that initial carbonate dissolution has been of source with $\delta^{13} \mathbf{C} \sim$ $0 \%$ but that the evolution at depth has been controlled by non-marine carbonate with $\delta^{13} \mathrm{C} \cong-7 \%$. Results show good correlation with ${ }^{4} \mathrm{He}$ as dating tool (Bath, Edmunds, and Andrews, 1979). 


\section{Low Wray Bay series}

Late-glacial sediment coll using Mackereth corer from Low Wray Bay, Windermere $\left(54^{\circ} 24^{\prime} \mathrm{N}, 2^{\circ} 57^{\prime} \mathrm{W}\right.$, Natl Grid Ref 35377013$)$. Sample depth increments (in $\mathrm{cm}$ ) are quoted relative to base of overlying laminated clay deposit which denotes onset of Loch Lomond Advance time. Coll 1973 and subm by W Tutin.

Several horizons in this sequence showed evidence of calcareous inclusion. Although samples were digested in $1 \mathrm{M} \mathrm{HCl}$ prior to ${ }^{14} \mathrm{C}$ assay persistent 'hard water effect' in these 'organic' ages cannot be discounted.

SRR-668. Low Wray Bay, 0 to $3 \mathrm{~cm}$

SRR-669. Low Wray Bay, 3 to $8.5 \mathrm{~cm}$

SRR-670. Low Wray Bay, 8.5 to $12 \mathrm{~cm}$

SRR-671. Low Wray Bay, 12 to $16 \mathrm{~cm}$

SRR-672. Low Wray Bay, 16 to $20 \mathrm{~cm}$

SRR-673. Low Wray Bay, 20 to $24 \mathrm{~cm}$

SRR-674. Low Wray Bay, 24 to $27 \mathrm{~cm}$

SRR-675. Low Wray Bay, 27 to $30 \mathrm{~cm}$

SRR-676. Low Wray Bay, 30 to $33 \mathrm{~cm}$

SRR-677. Low Wray Bay, 33 to $36 \mathrm{~cm}$

SRR-678. Low W ray Bay, 36 to $38 \mathrm{~cm}$

SRR-679. Low W ray Bay, 38 to $42 \mathrm{~cm}$

SRR-680. Low Wray Bay, 42 to $45 \mathrm{~cm}$

SRR-681. Low Wray Bay, 45 to $48 \mathrm{~cm}$

$$
\begin{aligned}
& \mathbf{1 2 , 2 7 0} \pm \mathbf{2 8 0} \\
& \delta^{1 s} C=-26.6 \% \\
& 11,350 \pm 90 \\
& \delta^{1 s} C=-24.1 \% \\
& 12,210 \pm 150 \\
& { }^{*} \delta^{13} C=-25.0 \% \\
& 12,130 \pm 180 \\
& \delta^{13} C=-21.1 \% \text { 。 } \\
& 12,110 \pm 130 \\
& \delta^{13} C=-26.1 \% \text { o } \\
& 12,520 \pm 150 \\
& \delta^{13} C=-23.9 \% \text { 。 } \\
& 12,500 \pm 120 \\
& \delta^{13} C=-26.6 \% \\
& 12,440 \pm 90 \\
& \delta^{13} C=-26.9 \% \\
& 12,920 \pm 120 \\
& \delta^{13} C=-26.9 \% \\
& 13,190 \pm 170 \\
& \delta^{13} C=-24.7 \% \\
& 12,570 \pm 240 \\
& \delta^{13} C=-24.2 \% \\
& 13,940 \pm 210 \\
& \delta^{13} C=-10.2 \% \\
& 13,860 \pm 270 \\
& \delta^{13} C=-17.0 \% \\
& 14,560 \pm 280 \\
& \delta^{13} C=-25.1 \% \text { o }
\end{aligned}
$$

$* \delta^{13} \mathrm{C}$ denotes estimate of stable isotope enrichment. 
SRR-682. Low W ray Bay, 48 to $55 \mathrm{~cm}$

$14,620 \pm 360$

$\delta^{13} \mathrm{C}=-23.4 \%$ o

General Comment (WT): samples span interstadial sediment between upper and lower varved clays. Absolute pollen diagram (Pennington, 1977) correlates well with that from neighboring site Blelham Bog (Pennington, 1975b) from which ${ }^{14} \mathrm{C}$ ages were Q-758 and I-3589 to -3598 . Agreement in ${ }^{14} \mathrm{C}$ age between boundaries of pollen zones in these two profiles suggests that hard-water effect is small, since it is unlikely to be same within interstadial organic matter of such different origin. In these samples from Low Wray Bay, in littoral of large lake Windermere, there is much allochthonous debris originating from terrestrial plants, whereas in small enclosed kettlehole of Blelham Bog, organic matter is autochthonous, derived from aquatic plants.

SRR-668 is unacceptably old, explained by presence of microcharcoal in sample. SRR-678 is unacceptably young; this cannot be explained. Ages have been used in definition of Windermere Interstadial of Late Devensian by Coope and Pennington (1978).

\section{SRR-694. Bingley (Trial Pit T35)}

$2210 \pm 170$

$\delta^{13} C=-26.5 \%$ o

Fragmented charcoal and organic detritus in soil at ca 0 to $20 \mathrm{~cm}$ below slip surface of shallow mudslide exposed in trial pit (T35) at Bingley, Yorkshire (53 $50^{\prime} \mathrm{N}, 1^{\circ} 50^{\prime} \mathrm{W}$, Natl Grid Ref SE 098 396). Coll 1974 and subm by $\mathrm{J}$ N Hutchinson.

\section{SRR-695. Bingley (Trial Pit T51)}

$6480 \pm 180$ $\delta^{13} C=-26.2 \%$

Organic detritus in clay gouge from slip surface, exposed at ca $2.3 \mathrm{~cm}$ depth in trial pit (T51), of large landslide near Bingley, Yorkshire $\left(53^{\circ}\right.$ $\left.50^{\prime} \mathrm{N}, 1^{\circ} 50^{\prime} \mathrm{W}\right)$. Coll 1975 and subm by $\mathrm{J} \mathrm{N}$ Hutchinson.

\section{SRR-759. Watermill Cove}

$22,710 \pm 200$ $\delta^{13} \mathrm{C}=-27.4 \%$ o

Alakli insoluble organic detritus in soil at ca $3.05 \mathrm{~m}$ below surface and ca $1.98 \mathrm{~m}$ into face of coastal exposure, Watermill Cove, St Mary's, Isles of Scilly (49॰ $56^{\prime} \mathrm{N}, 6^{\circ} 17^{\prime} \mathrm{W}$, Natl Grid Ref SV 925 122). Coll 1975 and subm by $\mathrm{N}$ R Page. Comment: (NRP): age is consistent with those pub from this stratum (Page, 1972), ie, 21,200 +900 ; GaK-2471 and $22,200 \pm 400 ;$ Т -833 .

\section{Morden Bog series}

Peat coll with Russian corer from two sites at Morden Bog, Wareham, Dorset $\left(50^{\circ} 4^{\prime} \mathrm{N}, 2^{\circ} 5^{\prime} \mathrm{W}\right.$, Natl Grid Refs (Site A) SY 916 912; (Site B) SY 924 892). Quoted sample depth increments (in $\mathrm{cm}$ ) relate to present bog surface. Coll 1975 by L E Haskins subm by K E Barber, Univ Southampton. 
SRR-786. Morden Bog (Site A),

$8650 \pm 220$ 200 to $205 \mathrm{~cm}$

$\delta^{1 s} C=-25.0 \%$ o

Gray clay with Phragmites rhizomes. Pollen analysis shows Betula dominant with substantial proportions of Pinus and Salix; many herbs also present including Artemisia, Helianthemum, Filipendula, Empetrum, and Calluna.

SRR-787. Morden Bog (Site B), 60 to $65 \mathrm{~cm}$ $\mathbf{3 5 0} \pm \mathbf{6 0}$ $\delta^{13} \mathrm{C}=-27.6 \%$

Rootlet peat with sand. Pollen shows marked decline in Corylus and progressive increase in Graminea and herbs.

SRR-788. Morden Bog (Site B), 100 to $105 \mathrm{~cm}$

$4180 \pm 150$ $\delta^{1 s} C=-27.7 \%$ 。

Rootlet peat. Pollen shows decline in Ulmus.

SRR-789. Morden Bog (Site B), 145 to $150 \mathrm{~cm}$

$$
\begin{array}{r}
\mathbf{6 9 8 0} \pm \mathbf{7 0} \\
\delta^{18} C=-28.3 \% 0
\end{array}
$$

Rootlet peat. Pollen indicates rational limit of Almus.

SRR-790. Morden Bog (Site B), 245 to $250 \mathrm{~cm}$

$7760 \pm 140$

$\delta^{13} \mathrm{C}=-27.6 \%$

Rootlet peat with Phragmites rhizomes. Pollen shows max level of Pinus and rational limit of Corylus.

General Comment (LEH): with exception of SRR-789 all ages are significantly younger than anticipated on basis of pollen analysis. This feature is attributed to penetration of younger Phragmites rhizomes from overlying sediment. While ages are of limited value to main objective of study, $i e$, determination of vegetational history of SE Dorset, they do serve to demonstrate the extreme care necessary in collection and preparation of such mire sediments for ${ }^{14} \mathrm{C}$ assay and the ease with which major disturbances in a sediment profile may be overlooked.

\section{Loweswater series}

Organic detritus in lake mud from cores taken with Mackereth corer in Loweswater, near Cockermouth, Cumbria $\left(54^{\circ} 35^{\prime} \mathrm{N}, 3^{\circ} 20^{\prime} \mathrm{W}\right.$, Natl Grid Ref NY 125 215). Quoted depth increments (in $\mathrm{cm}$ ) relate to present

\begin{tabular}{|c|c|c|}
\hline SRR-815. & $\begin{array}{l}\text { Loweswater (Core No. 751), } \\
86 \text { to } 96 \mathrm{~cm}\end{array}$ & $\begin{array}{r}\mathbf{5 8 0} \pm \mathbf{8 0} \\
\boldsymbol{\delta}^{13} \mathrm{C}=-28.9 \%\end{array}$ \\
\hline SRR-816. & $\begin{array}{l}\text { Loweswater (Core No. } 751 \text { ), } \\
106 \text { to } 116 \mathrm{~cm}\end{array}$ & $\begin{array}{r}1120 \pm \mathbf{8 0} \\
\delta^{13} C=-28.8 \% 0\end{array}$ \\
\hline SRR-817. & $\begin{array}{l}\text { Loweswater (Core No. } 753 \text { ), } \\
105 \text { to } 115 \mathrm{~cm}\end{array}$ & $\begin{array}{r}1130 \pm \mathbf{7 0} \\
\delta^{13} C=-29.2 \%\end{array}$ \\
\hline SRR-818. & $\begin{array}{l}\text { Loweswater (Core No. } 753 \text { ), } \\
120 \text { to } 130 \mathrm{~cm}\end{array}$ & $\begin{array}{r}\mathbf{8 9 0} \pm \mathbf{7 0} \\
\delta^{13} C=-29.9 \% o\end{array}$ \\
\hline
\end{tabular}
mud/water interface. Coll 1975 and subm by W Tutin. 
General Comment (WT): in this lake there is $20 \mathrm{~cm}$ band of gray clay within organic mud between 50 and $100 \mathrm{~cm}$ below mud surface. Purpose of radiocarbon assay was to learn age of organic clay immediately below clay band. Samples from two positions in lake (Cores 751 and 753), taken from this mud, show by anomalous sequence of ages that disorderly input of older organic residues from catchment, found at all other Lake District sites investigated, from ca 1100 BP onwards, had already begun in Loweswater before episode of redeposition in lake of gray clay from catchment where this clay represents fluvioglacial deposit of a pro-glacial lake much larger than present lake.

\section{Brotherswater series}

Organic detritus in lake mud from cores taken near middle of Brotherswater, Patterdale, Cumbria $\left(54^{\circ} 30^{\prime} \mathrm{N}, 2^{\circ} 55^{\prime} \mathrm{W}\right.$, Natl Grid Ref NY 402 126). Quoted depth increments (in $\mathrm{cm}$ ) relate to present mud/ water interface. Surface sediments (SRR-819 to -822) coll with $1 \mathrm{~m}$ Mackereth mini-corer, other data are for sediment in long core (No. 754) taken at same location. Coll 1975 and subm by W Tutin.

SRR-819. Brotherswater, 42 to $50 \mathrm{~cm}$

SRR-820. Brotherswater, 52 to $60 \mathrm{~cm}$

SRR-821. Brotherswater, 61 to $70 \mathrm{~cm}$

SRR-822. Brotherswater, 71 to $80 \mathrm{~cm}$

SRR-823. Brotherswater, 120 to $130 \mathrm{~cm}$

SRR-824. Brotherswater, 170 to $180 \mathrm{~cm}$

SRR-825. Brotherswater, 220 to $230 \mathrm{~cm}$

SRR-826. Brotherswater, 270 to $280 \mathrm{~cm}$

SRR-827. Brotherswater, 320 to $330 \mathrm{~cm}$

SRR-828. Brotherswater, 370 to $380 \mathrm{~cm}$

SRR-829. Brotherswater, 420 to $430 \mathrm{~cm}$

SRR-830. Brotherswater, 445 to $455 \mathrm{~cm}$

$$
\begin{array}{r}
\mathbf{8 4 0} \pm \mathbf{9 0} \\
\delta^{1 s} C=-28.7 \% o \\
\mathbf{8 8 0} \pm \mathbf{7 0} \\
\delta^{1 s} C=-28.4 \% o \\
\mathbf{8 6 0} \pm \mathbf{7 0} \\
\delta^{13} C=-28.4 \% o \\
\mathbf{9 2 0} \pm \mathbf{6 0} \\
\delta^{1 s} C=-27.9 \% \\
\mathbf{1 0 7 0} \pm \mathbf{6 0} \\
\delta^{13} C=-28.6 \% \circ \\
\mathbf{1 1 5 0} \pm \mathbf{6 0} \\
\delta^{13} C=-28.2 \% \\
\mathbf{1 1 3 0} \pm \mathbf{5 0} \\
\delta^{13} C=-28.5 \% \circ \\
\mathbf{1 4 1 0} \pm \mathbf{6 0} \\
\delta^{13} C=-28.4 \% o \\
\mathbf{1 4 0 0} \pm \mathbf{6 0} \\
\delta^{13} C=-28.6 \% \circ \\
\mathbf{1 6 4 0} \pm \mathbf{6 0} \\
\delta^{13} C=-28.3 \% o \\
\mathbf{2 1 9 0} \pm \mathbf{6 0} \\
\delta^{13} C=-28.1 \% o \\
\mathbf{2 1 2 0} \pm \mathbf{6 0} \\
\delta^{13} C=-27.9 \%
\end{array}
$$


General Comment (WT): these dates from sediment core $4.5 \mathrm{~m}$ long shows more rapid rate of sediment accumulation over past $2000 \mathrm{yr}$ than has yet been found in a British lake. A line fitted to SRR-826 to -830 shows mean accumulation rate of 0.2 to $0.25 \mathrm{~cm} / \mathrm{yr}$, and when extrapolated to mud surface, coincides with depth-time-scale for last $150 \mathrm{yr}$ determined by ${ }^{210} \mathrm{~Pb}$ dating. SRR-819 to -825 represent disorderly input from catchment of organic residues with ages in range 900 to $1000 \mathrm{yr}$. This has been found in all other Lake District lakes investigated; it may represent longcontinued input of organic soil horizon from hitherto wooded catchment, following deforestation (Pennington et al, 1976). Pollen evidence agrees with age of ca $2000 \mathrm{yr}$ BP for base of core.

\section{SRR-870. Cawood}

$10,470 \pm 60$ (o River Ouse, Yorkshire (53 $49^{\prime} \mathrm{N}, 1^{\circ} 7^{\prime} \mathrm{W}$, Natl Grid Ref 5813 3702). Coll 1973 and subm by R L Jones. Comment (RLJ): age confirms early Flandrian pollen spectra from deposit and assists in interpretation of local geomorphologic events including deposition of overlying sand.

\section{Fellend Moss series}

Ombrotrophic peat (Sphagnum/Eriophorum type) in depth profile through Fellend Moss, a deep raised bog $(8.5 \mathrm{~m}$ at sample site) overlying boulder clays and Carboniferous rocks of Middle Limestone Group, 3km NW of Haltwhistle, Northumberland $\left(54^{\circ} 59^{\prime} \mathrm{N}, 2^{\circ} 29^{\prime} \mathrm{W}\right.$, Natl Grid Ref NY 678 660). Quoted sample depths (in $\mathrm{cm}$ ) relate to bog surface. Coll 1975 by $\mathrm{G}$ Davies and subm by J Turner.

$\mathbf{4 3 0} \pm \mathbf{5 0}$

SRR-873. Fellend Moss, $64 \mathrm{~cm}$

Dates pollen evidence for final clearance of forest in area.

\section{SRR-874. Fellend Moss, $104 \mathrm{~cm}$}

Dates pollen evidence for brief episode of forest clearance.

SRR-875. Fellend Moss, $132 \mathrm{~cm}$

$1330 \pm 40$

Dates pollen evidence for end of major episode of forest clearance.

\section{SRR-876. Fellend Moss, $176 \mathrm{~cm}$}

$1950 \pm 50$

$\delta^{1 s} C=-26.3 \%$

Dates pollen evidence for beginning of major episode of forest clearance.

SRR-877. Fellend Moss, $320 \mathrm{~cm}$

$$
3690 \pm 60
$$

Dates pollen evidence for minor episode of forest clearance.

General Comment (GD): samples assoc with pollen diagram and date major forest clearance episodes. SRR-877 indicates short period of limited 
clearance in early Bronze age. More substantial clearance begins at $1950 \pm 50$ and lasts until $1330 \pm 40 \mathrm{BP}$, when some forest regeneration occurs. Another short, but pronounced episode reaches a peak at $950 \pm$ $40 \mathrm{BP}$, and final phase of clearance begins at $430 \pm 50 \mathrm{BP}$.

\section{Sweet Track Factory site series}

Peat in depth profile through location of prehistoric timber trackway (ca 60 to $70 \mathrm{~cm}$ depth in this sec) at Sweet Track Factory site, Somerset $\left(51^{\circ} 9^{\circ} \mathrm{N}, 2^{\circ} 49^{\prime} \mathrm{W}\right.$, Natl Grid Ref ST 425404$)$. Details of site and system of prehistoric trackways of Somerset Levels are described in Coles, Hibbert, and Orme (1973) and related radiocarbon age determinations are listed in Coles and Coles (1975). Quoted sample depth increments (in $\mathrm{cm}$ ) related to ground surface. Coll 1975 and subm by $\mathrm{F}$ A Hibbert and S C Heckett, Liverpool Polytechnic.$$
\text { S600 } \pm 40
$$

SRR-878. Sweet Track Factory site, 3 to $5 \mathrm{~cm} \quad \delta^{13} C=-27.9 \%$ Sphagnum/Calluna/Eriophorum peat.

$\mathbf{4 0 5 0} \pm \mathbf{5 0}$

SRR-879. Sweet Track Factory site, 20 to $22 \mathrm{~cm} \quad \delta^{t s} C=-26.8 \%$ Sphagnum/Calluna/Eriophorum peat.

SRR-880. Sweet Track Factory site, 31 to $33 \mathrm{~cm} \quad \delta^{13} C=-26.7 \%$ o Fenwood peat.

$4410 \pm 50$
SRR-881. Sweet Track Factory site, 55 to $57 \mathrm{~cm} \quad \delta^{13} C=-26.9 \%$ o $\mathbf{4 7 4 0} \pm \mathbf{5 0}$

SRR-882. Sweet Track Factory site, 79 to $81 \mathrm{~cm} \quad \delta^{13} C=-27.4 \%$ Phragmites fen peat.

$\begin{array}{rr}4850 \pm 50 & \mathbf{5 0}\end{array}$ Phragmites peat.

General Comment (FAH/SCB): dates around track level (SRR-881 and -882) are younger than those obtained from timbers of Neolithic track itself (Coles and Coles, 1975). Major clearance phase occurs between SRR-882 and -883 and minor one between SRR-879 and -878. These agree closely in date and character with those noted at Abbot's Way site.

\section{Meare Lake series}

Peat in monolith sec cut from bank at Meare Lake, Somerset $\left(51^{\circ}\right.$ $10^{\prime} \mathrm{N}, 2^{\circ} 47^{\prime} \mathrm{W}$, Natl Grid Ref ST 444406$)$. Stratigraphy of site and description of Bronze age Meare Heath trackway at this site are given in Coles and Orme (1976). Related radiocarbon age determinations are listed in Coles and Coles (1975), and in this date list (SRR-534 to -543, -878 to -883 , and -1011 to -1014 ). Quoted sample depth increments (in $\mathrm{cm}$ ) relate to present bog surface. Coll 1974 and subm by S C Beckett and F A Hibbert. 
SRR-910. Meare Lake, 11 to $13 \mathrm{~cm}$

Fresh moss peat.

SRR-911. Meare Lake, 27 to $29 \mathrm{~cm}$

Fresh moss peat.

SRR-912. Meare Lake, 49 to $51 \mathrm{~cm}$ Humified moss peat, a little Cladium.

SRR-913. Meare Lake, 69 to $71 \mathrm{~cm}$

Fresh moss peat.

SRR-914. Meare Lake, 85 to $87 \mathrm{~cm}$

Cladium peat.

SRR-915. Meare Lake, 109 to $111 \mathrm{~cm}$

Calluna/Eriophorum peat.

SRR-916. Meare Lake, 129 to $131 \mathrm{~cm}$

Calluna/Eriophorum peat.

SRR-917. Meare Lake, 145 to $147 \mathrm{~cm}$

Eriophorum peat.

$$
\begin{array}{r}
\mathbf{1 4 1 0} \pm \mathbf{5 0} \\
\delta^{1 s} C=-26.6 \%
\end{array}
$$

$\mathbf{1 7 5 0} \pm \mathbf{5 0}$

$\delta^{19} C=-27.2 \%$

$$
\mathbf{2 0 6 0} \pm \mathbf{5 0}
$$$$
\delta^{13} C=-26.6 \%
$$

$\mathbf{2 2 5 0} \pm \mathbf{5 0}$
$\delta^{13} C=-27.9 \%$

$2620 \pm 50$

$\delta^{13} C=-27.5 \%$

$$
\mathbf{3 7 2 0} \pm \mathbf{5 0}
$$$$
\delta^{13} C=-27.8 \% \text { o }
$$

$\mathbf{3 8 0 0} \pm \mathbf{5 0}$

$\delta^{13} C=-28.5 \%$

$4000 \pm 50$
$\delta^{13} C=-26.7 \%$

General Comment (SCB/FAH): dates delimit clearance phases separated by woodlands regeneration and overlap with those from Abbot's Way and Sweet Track Factory sites. These dates also show slight woodland regeneration between SRR-913 and -912, and extensive clearance activity after latter. SRR-910 is youngest date yet obtained from peat of Somerset Levels and may be very close to cessation of peat formation in area. Dates are being used to calculate values of absolute pollen influx.

\section{Blea Tarn series}

Organic detritus in uppermost $75 \mathrm{~cm}$ of sediment at Blea Tarn, Langdale, Cumbria (54 $26^{\prime} \mathrm{N}, 3^{\circ} 05^{\prime} \mathrm{W}$, Natl Grid Ref NY 293 042). Sediment core taken with Mackereth mini-corer at approx position of long core. Coll 1971 and dated SRR-16 to -23 (R, 1973, v 15, p 557-558). Quoted sample depths (in $\mathrm{cm}$ ) relate to present mud/water interface. Coll 1975 and subm by W Tutin.

SRR-955. Blea Tarn, 31 to $39 \mathrm{~cm}$

SRR-956. Blea Tarn, 41 to $49 \mathrm{~cm}$

SRR-957. Blea Tarn, 51 to $60 \mathrm{~cm}$

$$
\begin{array}{r}
\mathbf{3 9 4 0} \pm \mathbf{5 0} \\
\delta^{1 s} C=-29.2 \% \\
\mathbf{4 1 6 0} \pm \mathbf{5 0} \\
\delta^{1 s} C=-28.9 \% \\
\mathbf{4 3 9 0} \pm \mathbf{5 0} \\
\delta^{1 s} C=-28.9 \%
\end{array}
$$


SRR-958. Blea Tarn, 60 to $70 \mathrm{~cm}$

$4480 \pm 50$

SRR-959. Blea Tarn, 70 to $75 \mathrm{~cm}$

$\delta^{13} C=-29.0 \%$

$4290 \pm 50$

$\delta^{13} C=-29.1 \%$

General Comment (WT): ages are difficult to explain. $1 \mathrm{~m}$ core from which they were taken represents topmost meter of core from which came samples SRR-16 to -23 , and -959 agrees well with $-16 ; 4475 \pm 70$ at 94 to $100 \mathrm{~cm}$ depth. Either some hitherto undetected accident is possible while sampling with $1 \mathrm{~m}$ corer, or accumulation in this lake (which is known to have been comparatively slow) has for last $4000 \mathrm{yr}$ included organic material of anomalously old ${ }^{14} \mathrm{C}$ age. This must be investigated by further research.

\section{Ennerdale Water series}

Organic detritus in uppermost sediments of Ennerdale Water, Cumbria $\left(54^{\circ} 31^{\prime} \mathrm{N}, 3^{\circ} 22^{\prime} \mathrm{W}\right.$, Natl Grid Ref NY 105150$)$. Sediment core taken with Mackereth mini-corer at center buoy position of long $(6 \mathrm{~m})$ core coll 1971 and dated SRR-178 to -184 (R, 1974, v 16, p 246-247). Quoted sample depths (in $\mathrm{cm}$ ) relate to present mud/water interface. Coll 1976 and subm by W Tutin.

\section{SRR-960. Ennerdale Water, 21 to $29 \mathrm{~cm}$}

SRR-961. Ennerdale Water, 31 to $39 \mathrm{~cm}$

SRR-962. Ennerdale Water, 41 to $49 \mathrm{~cm}$

SRR-963. Ennerdale Water, 51 to $59 \mathrm{~cm}$

SRR-964. Ennerdale Water, 60 to $69 \mathrm{~cm}$

SRR-965. Ennerdale Water, 70 to $79 \mathrm{~cm}$

SRR-966. Ennerdale Water, 80 to $86 \mathrm{~cm}$

$$
\begin{array}{r}
930 \pm \mathbf{1 0 0} \\
\delta^{1 s} C=-25.0 \% \\
\mathbf{1 1 1 0} \pm \mathbf{8 0} \\
\delta^{13} C=-26.7 \% o \\
\mathbf{1 2 3 0} \pm \mathbf{7 0} \\
\delta^{13} C=-24.3 \% o \\
\mathbf{1 6 6 0} \pm \mathbf{6 0} \\
\delta^{13} C=-26.7 \% 0 \\
\mathbf{1 5 8 0} \pm \mathbf{5 0} \\
\delta^{13} C=-28.1 \% 0 \\
\mathbf{1 2 5 0} \pm \mathbf{5 0} \\
\delta^{13} C=-27.5 \% 0
\end{array}
$$

$1070 \pm 60$

$\delta^{13} \mathrm{C}=-28.4 \%$

General Comment (WT): samples are from $1 \mathrm{~m}$ core representing top of long core previously dated (SRR-178 to -184 , and -307 to -309 ). Plot of ages (adding $20 \mathrm{~cm}$ to measurements in long core because of loss of this amount of surface sediment) shows that prolongation to mud surface of linear depth-time-scale fitted to SRR-966 and -179 to -183 coincides with overall depth-time-scale for last $150 \mathrm{yr}$ determined by ${ }^{210} \mathrm{~Pb}$ dating. As in Brotherswater and Blelham Tarn profiles, samples overlying date of $1000 \mathrm{yr}$ on this overall depth-time-scale are of anomalously old ${ }^{14} \mathrm{C}$ age. Work on other lakes in this region has established that extensive de- 
forestation took place between 1700 and $1400 \mathrm{yr}$ ago. Work on Ennerdale Water will be continued by further dating of sec between SRR-966 and -197, in order to date first input of material of anomalous ${ }^{14} \mathrm{C}$ age in profile.

\section{Silpho Moor series}

Humus podsol overlying Calcareous Grit at Silpho Moor, Scarborough, Yorkshire (54 $20^{\prime} \mathrm{N}, 0^{\circ} 45^{\prime} \mathrm{W}$, Natl Grid Ref 494 596). Coll 1976 and subm by J E Satchell, Inst Terrestrial Ecology.

\section{SRR-997. Silpho Moor}

Ironpan $\left(\mathrm{B}_{\mathrm{Fe}}\right.$ horizon) ca $2 \mathrm{~mm}$ thick in soil profile.

\section{SRR-998. Silpho Moor}

Humus (B horizon) immediately overlying ironpan in soil profile. General Comment (JES): samples were coll from podzolized heather moor adjacent to experimental plots set up by G W Dimbleby (1953) to establish effect of birch as soil improver. Radiocarbon dates suggest that organic complexes of ironpan are resistant to microbial decomposition and may therefore not be readily mobilized by birch rhizoflora.

\section{Abbot's Way series}

Peat in open monolith coll from excavation pit at Abbot's Way (a Neolithic trackway), Somerset $\left(51^{\circ} 10^{\prime} \mathrm{N}, 2^{\circ} 50^{\prime} \mathrm{W}\right.$, Natl Grid Ref ST 421 427). Site described in detail and related ${ }^{14} \mathrm{C}$ dates for trackway reported in Coles and Hibbert (1968) and Coles, Hibbert, and Clements (1970). Quoted depths (in $\mathrm{cm}$ ) relate to present ground surface. Coll 1974 by $\mathrm{F}$ A Hibbert and S C Beckett; subm by F A Hibbert.

SRR-1011. Abbot's Way, 5 to $7 \mathrm{~cm}$ Sphagnum peat.

SRR-1012. Abbot's Way, 17 to $19 \mathrm{~cm}$ Sphagnum peat.

SRR-1013. Abbot's Way, 25 to $27 \mathrm{~cm}$ Sphagnum/Eriophorum peat.

SRR-1014. Abbot's Way, 37 to $39 \mathrm{~cm}$ Fen peat with Cladium rhizomes.

SRR-534. Abbot's Way, 47 to $49 \mathrm{~cm}$

Humified peat (Sphagnum-calluna-eriophorum) overlying trackway at ca 70 to $75 \mathrm{~cm}$ depth in profile.

$$
\begin{array}{r}
1950 \pm 40 \\
\delta^{13} C=-27.1 \% \circ \\
2090 \pm \mathbf{5 0} \\
\delta^{13} C=-27.0 \% \circ
\end{array}
$$

$$
\begin{array}{r}
\mathbf{2 3 2 0} \pm \mathbf{5 0} \\
\delta^{13} C=-25.7 \% 0
\end{array}
$$

$$
\mathbf{2 8 0 0} \pm \mathbf{5 0}
$$$$
\delta^{19} C=-26.5 \%
$$

$$
\mathbf{3 4 2 0} \pm \mathbf{5 0}
$$

$\delta^{13} C=-27.4 \%$ 
SRR-535. Abbot's Way, 66 to $68 \mathrm{~cm}$

$3600 \pm 50$

Humified peat (Sphagnum-calluna-eriophorum) just overlying trackway.

SRR-536. Abbot's Way, 87 to $89 \mathrm{~cm}$

$3910 \pm 50$

Humified peat (Sphagnum-calluna-eriophorum).

SRR-537. Abbot's Way, 99 to $101 \mathrm{~cm}$

$4100 \pm 50$

Humified peat (Sphagnum-calluna-eriophorum).

SRR-538. Abbot's Way, 118 to $120 \mathrm{~cm}$

$\mathbf{4 2 3 0} \pm \mathbf{5 0}$

Humified peat (Sphagnum-calluna-eriophorum).

SRR-539. Abbot's Way, 133 to $135 \mathrm{~cm}$

Humified peat (Sphagnum-calluna-eriophorum).

SRR-540. Abbot's Way, 150 to $152 \mathrm{~cm}$ $\delta^{13} C=-26.2 \%$ $\delta^{13} C=-28.2 \%$ $\delta^{13} \mathrm{C}=-28.8 \%$

Humified peat (Sphagnum-calluna-eriophorum) from just above 'elm decline'. $\delta^{13} C=-27.4 \%$

$4510 \pm 50$ $\delta^{13} \mathrm{C}=-27.8 \%$

SRR-541. Abbot's Way, 160 to $162 \mathrm{~cm}$ $4660 \pm 60$

Fenwood peat corresponds to 'elm decline'.

SRR-542. Abbot's Way, 171 to $173 \mathrm{~cm}$

Fenwood peat corresponds to 'elm decline'. $\delta^{13} C=-26.8 \%$

SRR-543. Abbot's Way, 183 to $185 \mathrm{~cm}$ $4770 \pm 50$

Fenwood peat corresponds to pre-'elm decline'. $\delta^{13} C=-27.9 \%$ $4800 \pm 50$ $\delta^{13} C=-30.0 \%$

General Comment (SCB): dates delimit clearance phases between SRR542 and $-539,-536$ and -535 , and continued extensive woodland clearance after SRR-534. Age profile used to calculate absolute pollen influx values (Beckett and Hibbert, 1976).

\section{Steng Moss series}

Ombrotrophic peat in profile through raised peat bog, ca $750 \mathrm{~cm}$ total depth, Steng Moss, Northumberland $\left(55^{\circ} 13^{\prime} \mathrm{N}, 2^{\circ} 03^{\prime} \mathrm{W}\right.$, NatI Grid Ref NY 965 913). Quoted sample depths (in $\mathrm{cm}$ ) relate to present bog surface. Coll 1975 by G Davies, subm by J Turner.

$\begin{array}{llr}\text { SRR-1041. } & \text { Steng Moss, } 61.5 \text { to } 63 \mathrm{~cm} & 1090 \pm \mathbf{4 0} \\ \text { SRR-1042. } & \text { Steng Moss, 151.5 to } 153 \mathrm{~cm} & \delta^{13} C=-27.5 \% \\ & & \mathbf{2 5 3 0} \pm \mathbf{4 0} \\ \text { SRR-1043. } & \text { Steng Moss, } 179 \text { to } 184 \mathrm{~cm} & \mathbf{2 5 9 0} \pm \mathbf{5 0} \\ & & \delta^{1 s} C=-27.4 \%\end{array}$


SRR-1044. Steng Moss, 211 to $216 \mathrm{~cm}$

SRR-1045. Steng Moss, 255 to $260 \mathrm{~cm}$

$$
\begin{array}{r}
\mathbf{3 0 2 0} \pm \mathbf{5 0} \\
\delta^{13} C=-27.5 \% 0 \\
\mathbf{3 6 0 0} \pm \mathbf{5 0} \\
\delta^{13} C=-26.7 \% 0
\end{array}
$$

General Comment (GD/JT): SRR-1043 to -1045 date max of three separate "Landnam" type clearance periods. SRR-1042 shows beginning of long period of clearance, limited at first but later becoming more extensive. SRR-1041 dates max of significant but comparatively short period of forest clearance.

\section{SRR-1130. River Ancholme}

$$
\begin{array}{r}
4050 \pm 50 \\
\delta^{1 s} C=-26.0 \%
\end{array}
$$

Cellulose fraction of wood in tree trunk buried at ca $2.2 \mathrm{~m}$ depth in peat and overlain by estuarine sediments on $W$ bank of Ancholme $R$, Humberside $\left(53^{\circ} 33^{\prime} \mathrm{N}, 0^{\circ} 31^{\prime} \mathrm{E}\right.$, Natl Grid Ref SE 9922 0781). Coll 1976 and subm by T P Fletcher, Inst Geol Sci, Leeds. Comment (TPF): since peat is overlain by estuarine silts and clays, date indicates that sea level was raised after formation of peat.

\section{Finland}

\section{Lansi Hiidenlampi series}

Organic detritus in lake mud cored from deepest part (ca $8 \mathrm{~m}$ water column) of Lansi Hiidenlampi, small lake in Oulanka Natl Park, Kuusamo Prov ( $66^{\circ} 22^{\prime} \mathrm{N}, 29^{\circ} 20^{\prime} \mathrm{E}$ ). Quoted sample depths (in $\mathrm{cm}$ ) refer to present water/mud interface. Coll 1974 and subm by P E O'Sullivan, Plymouth Polytechnic.

Samples were digested in $2 \mathrm{M} \mathrm{HCl}$ to remove possible carbonate inclusions in mineral matrix from suspected hard-water environment.

SRR-871. Lansi Hiidenlampi, 0 to $6 \mathrm{~cm}$

SRR-872. Lansi Hiidenlampi, 36 to $41 \mathrm{~cm}$
$900 \pm 80$ $\delta^{19} C=-29.9 \%$

$$
4690 \pm 80
$$

$\delta^{13} C=-30.5 \%$ o

General Comment (PEO'S): SRR-872 spans sediments containing important pollen-analytic marker horizon of Picea (Spruce)-rise, and agrees well with date obtained for this horizon by Hicks (1975) from bog at Kangerjoki, also in Kuusamo area. Thus, despite apparent slow accumulation rate, hard-water effects characteristic of Oulanka Park area (Donner, Jungner, and Vasari, 1971), may possibly be absent from Hiidenlampi.

\section{Kourulampi series}

Organic lake mud coll with Gilson corer from Kourulampi, Oulanka Natl Park, Kuusamo Prov ( $66^{\circ} 22^{\prime}$ N, 29 $21^{\circ}$ E). Core taken at deepest part of lake (ca $6 \mathrm{~m}$ water column) and quoted sample depths (in $\mathrm{cm}$ ) relate to present mud/water interface. Coll 1974 and subm by $\mathbf{P}$ E O'Sullivan. 
SRR-1046. Kourulampi, 4 to $10 \mathrm{~cm}$

SRR-1047. Kourulampi, 34 to $40 \mathrm{~cm}$

$1450 \pm 120$ $\delta^{13} C=-20.1 \%$

$3430 \pm 90$ $\delta^{13} \mathrm{C}=-28.3 \%$

General Comment: sediments were pretreated by digestion in $2 \mathrm{M} \mathrm{HCl}$ to remove possible calcareous inclusions due to hard water environment.

\section{Vuokonjarvi series}

Gyttja in freshwater sediment core taken with $6 \mathrm{~m}$ Mackereth corer from Vuokonjarvi, Karelia, Finland $\left(63^{\circ} 40^{\prime} \mathrm{N}, 28^{\circ} 20^{\prime} \mathrm{E}\right)$. Sample depths (in $\mathrm{m}$ ) are quoted for midpoint of increment analyzed relative to present mud/water interface. Coll 1975 by R Thompson subm by J Stober, Univ Edinburgh.

SRR-1048. Vuokonjarvi, 1.47 to $1.61 \mathrm{~m}$

SRR-1049. Vuokonjarvi, 1.96 to $2.1 \mathrm{~m}$

SRR-1050. Vuokonjarvi, 2.36 to $2.5 \mathrm{~m}$

SRR-1051. Vuokonjarvi, 3.16 to $3.3 \mathrm{~m}$

SRR-1052. Vuokonjarvi, 3.73 to $3.87 \mathrm{~m}$

SRR-1053. Vuokonjarvi, 4.53 to $4.67 \mathrm{~m}$

$$
\begin{array}{r}
\mathbf{5 3 1 0} \pm \mathbf{7 0} \\
\delta^{1 s} C=-32.3 \% \\
\mathbf{7 3 0 0} \pm \mathbf{8 0} \\
\delta^{1 s} C=-30.3 \% \\
\mathbf{8 3 4 0} \pm \mathbf{9 0} \\
\delta^{1 s} C=-30.4 \% \\
\mathbf{1 1 , 0 8 0} \pm \mathbf{1 5 0} \\
\delta^{1 s} C=-27.7 \% 0 \\
+\mathbf{2 5 0} \\
\mathbf{1 2 , 2 8 0}-\mathbf{2 4 0} \\
\delta^{1 s} C=-27.0 \% \\
+\mathbf{1 2 2 0} \\
\mathbf{2 2 , 9 5 0}-\mathbf{1 0 6 0} \\
\delta^{1 s} C=-27.1 \%
\end{array}
$$

General Comment (JS): dates are much greater than predicted by comparison of magnetic declination record in sediment with that of Windermere, England (Thompson, 1973). Deglaciation of area ended ca $8000 \mathrm{yr}$ ago. ${ }^{14} \mathrm{C}$ deficiency attributed to presence of 'infinitely old' carbon in sediment.

\section{SRR-1054. Kiteenjarvi}

$7610 \pm 100$

$\delta^{13} \mathrm{C}=-30.2 \%$

Organic detritus in 5.05 to $5.21 \mathrm{~m}$ depth increment of sediment core taken from central region of Kiteenjarvi, E Finland $\left(65^{\circ} 15^{\prime} \mathrm{N}, 30^{\circ} 30^{\prime} \mathrm{E}\right)$. Sample corresponds to clay/gyttja boundary in sediment profile assoc with change in magnetic properties. Coll 1975 by R Thompson; subm by J Stober.

\section{Paajarvi series}

Gyttja in freshwater sediment core taken with $6 \mathrm{~m}$ Mackereth corer from deep part (ca $39.6 \mathrm{~m}$ water column) of Paajarvi, S Finland $\left(61^{\circ} 04^{\prime}\right.$ 
$\mathrm{N}, 25^{\circ} 08^{\prime} \mathrm{E}$ ). Quoted sample depths (in $\mathrm{m}$ ) relate to present mud/water interface. Coll 1975 by R Thompson; subm by J Stober.

SRR-1055. Paajarvi, 1.92 to $2.08 \mathrm{~m}$

SRR-1056. Paajarvi, 2.42 to $2.58 m$

SRR-1057. Paajarvi, 2.92 to $3.08 \mathrm{~m}$

SRR-1058. Paajarvi, 3.64 to 3.8m

SRR-1059. Paajarvi, 4.67 to $4.83 \mathrm{~m}$

SRR-1060. Paajarvi, 5.14 to 5.3m
$2390 \pm 60$ $\delta^{13} \mathrm{C}=-28.8 \%$

$\mathbf{2 8 3 0} \pm \mathbf{5 0}$ $\delta^{1 s} C=-29.6 \%$ o

$\mathbf{3 0 8 0} \pm \mathbf{5 0}$ $\delta^{13} \mathrm{C}=-28.8 \%$

$\mathbf{3 7 0 0} \pm \mathbf{5 0}$ $\delta^{13} C=-29.2 \%$

$4330 \pm 50$ $\delta^{1 s} \mathrm{C}=-29.1 \%$

$4880 \pm 50$

$\delta^{13} C=-29.3 \%$

General Comment (JS): ages estimated for these sediments by comparison of magnetic declination record with that of Windermere (Thompson, 1973) are less than above, although extent of this difference decreases down the core.

\section{Lake Trikhonis series}

E. Greece

Organic detritus in sediment from Lake Trikhonis $\left(38^{\circ} 18^{\prime} \mathrm{N}, 21^{\circ}\right.$ $18^{\prime}$ E). Samples from Core No. 3 taken with Mackereth-type corer. Quoted depth intervals (in $\mathrm{cm}$ ) relate to top of recovered core overlain by ca $50 \mathrm{~cm}$ moist sediment and $49.7 \mathrm{~m}$ water column. Coll 1974 and subm by P W Readman, Univ Edinburgh.

SRR-698. Lake Trikhonis, 67 to $101 \mathrm{~cm}$

SRR-884. Lake Trikhonis, 249 to $282 \mathrm{~cm}$

SRR-699. Lake Trikhonis, 526 to $559 \mathrm{~cm}$

$$
\begin{array}{r}
\mathbf{2 2 9 0} \pm \mathbf{9 0} \\
\delta^{13} C=-26.8 \% \\
\mathbf{5 0 9 0} \pm \mathbf{8 0} \\
\delta^{13} C=-30.0 \% \\
\mathbf{5 7 7 0} \pm \mathbf{9 0} \\
\delta^{13} C=-26.8 \% o
\end{array}
$$

General Comment (PWR): dates period of ca $1800 \mathrm{yr}$ for palaeomagnetic oscillations of inclination and rather more, ie, 2500 to 3000 yr for declination swings.

\section{Lake Volvi series}

Organic detritus in sediment profile, Core No. 5, taken with Mackereth corer under ca $20 \mathrm{~m}$ water column Lake Volvi $\left(40^{\circ} 42^{\prime} \mathrm{N}, 23^{\circ} 30^{\prime} \mathrm{E}\right)$. Quoted depths (in $\mathrm{cm}$ ) relate to uppermost level recoverable by corer. Coll 1974 and subm by P W Readman and K M Creer.

$$
\begin{array}{llr}
\text { SRR-885. } & \text { Lake Volvi, Core 5, 44 to 80cm } & \begin{array}{r}
\mathbf{8 9 0} \pm \mathbf{5 0} \\
\delta^{1 s} C=-25.6 \%
\end{array} \\
\text { SRR-886. } & \text { Lake Volvi, Core 5, 304 to 337 cm } & \delta^{1 s} C=-29.4 \%
\end{array}
$$


General Comment (KMC): this core has since been dated from its palaeomagnetic declination and inclination record. Ages so obtained are $<200$ yr for level of SRR-885 and 300 to 500 years for level of SRR-886 (Creer, Readman, and Papamarinopoulos, 1980).

\section{Lake Vegoritis series}

Organic detritus in sediment profiles taken with Mackereth corer in Lake Vegoritis, Greece $\left(40^{\circ} 42^{\prime} \mathrm{N}, 21^{\circ} 48^{\prime} \mathrm{E}\right)$. Core No. 7 taken under $30.8 \mathrm{~m}$ water column. Core No. 4 under $51.2 \mathrm{~m}$ water. Quoted depths (in $\mathrm{cm}$ ) in profile relate to uppermost level recoverable by corer. Coll 1974 and subm by $\mathbf{P}$ W Readman and S Papamarinopoulos.

SRR-887. Lake Vegoritis, Core 7, 35 to $71 \mathrm{~cm} \quad \delta^{13} C=-25.4 \%$ o

SRR-888. Lake Vegoritis, Core 7, 161 to $187 \mathrm{~cm} \delta^{13} C=-22.2 \%$

$$
5410 \pm 70
$$

SRR-889. Lake Vegoritis, Core 7, 291 to $319 \mathrm{~cm} \delta^{1 s} C=-34.2 \%$

SRR-890. Lake Vegoritis, Core 4, 374 to $424 \mathrm{~cm} \delta^{1 s} C=-25.5 \%$ General Comment (KMC): cores have since been dated from their magnetic declination and inclination records. Ages so obtained are, for level of SRR-887, 200 to $300 \mathrm{yr}$, SRR-888, 700 to $800 \mathrm{yr}$, SRR-889, 2600 to $2800 \mathrm{yr}$, and SRR-890, 1600 to $1800 \mathrm{yr}$ BP (Creer, Readman, and Papamarinopoulos, 1980).

\section{SRR-793. Melos}

$2820 \pm 140$ $\delta^{13} C=-26.0 \%$

Organic detritus in horizon, ca $10 \mathrm{~cm}$ thick, overlain by $80 \mathrm{~cm}$ scree colluvium and exposed in dry stream channel in Upper Phylakopi Valley, Melos (36 $\left.45^{\prime} \mathrm{N}, 24^{\circ} 31^{\prime} \mathrm{E}\right)$. Coll 1974 and subm by D A Davidson and C Tasker, St David's Coll, Univ Wales. Comment (DAD): date suggests accelerated erosion of Melian landscape began immediately at end of Aegean Late Bronze age and at onset of so-called 'Dark Age'.

\section{F. Iceland \\ SRR-1030. Asmundarnes

$$
\begin{array}{r}
9930 \pm \mathbf{8 0} \\
\delta^{1 s} C=+1.1 \% o
\end{array}
$$

Fragmented shell (Balanus spp) excavated from glacio-marine deposit of shelly clay at ca $1 \mathrm{~m}$ above msl on $\mathrm{N}$ side of head of fjord, Asmundarnes, Bjarnarfjordur $\left(65^{\circ} 46^{\prime} \mathrm{N}, 21^{\circ} 28^{\prime} \mathrm{W}\right)$. Coll 1975 and subm by B S John, Univ Durham. Comment (BSJ): confirms Late-glacial age of this deposit, and indicates presence of wasting ice at E coast of Vestfirdir following Budi (Zone III) re-advance.

\section{SRR-1031. Reykholar}

$10,460 \pm 100$ $\delta^{13} \mathrm{C}=-0.2 \%$

Fragmented shell (Balanus spp) excavated from suspected glaciomarine deposit of shelly clay at ca $8.5 \mathrm{~m}$ alt OD, Reykholar, Breidafjordur 
$\left(65^{\circ} 27^{\prime} \mathrm{N}, 22^{\circ} 12^{\prime} \mathrm{W}\right)$. Coll 1975 and subm by B S John. Comment (BSJ): confirms presence of Budi (Zone III) glacier ice on S coast of Vestfirdir. Sea level at the time must have been at least $8 \mathrm{~m}$ above present msl.

\section{SRR-1032. Trimbilsstadir}

$$
1050 \pm 60
$$

Cellulose extracted from wood fragment buried at ca $150 \mathrm{~cm}$. in moraine ridge, Trimbilsstadir, Kaldalon $\left(66^{\circ} 06^{\prime} \mathrm{N}, 22^{\circ} 20^{\prime} \mathrm{W}\right.$, UTM Grid Ref VP 389 315). Coll 1975 and subm by B S John. Comment (BSJ): indicates a major re-advance of Kaldalon glacier (Drangajokull) sometime after $1050 \mathrm{yr}$ BP.

\section{SRR-1033. Botnsa}

$\mathbf{3 8 5 0} \pm \mathbf{5 0}$

Cellulose extracted from wood fragment (Betula pu $340 \mathrm{~cm}$ depth in peat $/ \mathrm{silt}$ deposit at Bofmescens) at ca Botnsa, Dryafjordur $\left(65^{\circ} 50^{\prime} \mathrm{N}, 23^{\circ}\right.$ $10^{\prime}$ W, UTM Grid Ref VP 006 038). Coll 1974 and subm by B S John. Comment (BSJ): confirms suggestion that thick peat deposits with Betula fragments date from Later Birch period of Iceland (5000 to $2500 \mathrm{yr}$ BP). Probably dates Holocene climatic optimum for N W Peninsula.

\section{G. Indonesia}

\section{SRR-464. Danau Di-atas, 820 to $840 \mathrm{~cm}$}

$$
\begin{array}{r}
\mathbf{2 4 4 0} \pm \mathbf{7 0} \\
\delta^{1 s} C=-22.7 \% \text { o }
\end{array}
$$

Fine detritus mud in core (borehole Outlet Bay 3) from Danau (Lake) Di-atas, Alahan Panjang, W Sumatra $\left(1^{\circ} 4^{\prime} \mathrm{S}, 100^{\circ} 46^{\prime} \mathrm{E}\right)$ alt 1530m. Coll 1972 and subm by J R Flenley, Univ Hull. Comment (JRF): date is min for start of deposition in Outlet Bay. Present outlet has probably been adopted only recently; this date may provide min age for change of outlet (Morley, 1980a,b).

\section{$12,630 \pm 200$}

Fine detritus mud at base of Core (Taluk Dalam) from edge of Danau Di-atas (SRR-464). Coll 1972 and subm by J R Flenley. Comment (JRF): date is min for origin of lake basin by tectonic movement. Material coll later from same swamp, in a longer core, has given dates back to ca 31,000 BP (SRR-1346 to -1350 and GX-4915 and -4916). This core is undergoing pollen analysis.

\section{SRR-466. Telago Swamp, 1000 to $1005 \mathrm{~cm}$}

$9100 \pm 200$ Ala Alahan Panjang, W Sumatra $\left(1^{\circ} 3^{\prime} \mathrm{S}, 100^{\circ} 46^{\prime} \mathrm{E}\right)$ alt ca $1500 \mathrm{~m}$. Coll 1972 and subm by J R Flenley. Comment (JRF): date is min for origin of this volcano-tectonic feature and also a dated horizon in pollen diagram under construction.

\section{Padang series, Sumatra}

Coarse detritus mud in cores from Danau (Lake) Padang, LoloGedang, Kerinci, Jambi $\left(2^{\circ} 14^{\prime} \mathrm{S}, 101^{\circ} 31^{\prime} \mathrm{E}\right)$ alt $950 \mathrm{~m}$. Quoted sample 
depth increments (in $\mathrm{cm}$ ) relate to mud surface. Coll 1972 and subm by R J Morley, Univ Hull.

SRR-468. Padang, 1A, 565 to $858 \mathrm{~cm}$

SRR-469. Padang, 1A, 1285 to $1295 \mathrm{~cm}$

SRR-470. Padang, 1B, 1575 to $1585 \mathrm{~cm}$ $\mathbf{3 8 5 0} \pm \mathbf{1 0 0}$ $\delta^{18} C=-28.3 \%$ $7510 \pm 90$ $\delta^{13} \mathrm{C}=-29.9 \%$ $8270 \pm 130$ $\delta^{13} C=-29.5 \%$

$8600 \pm 90$ $\delta^{13} \mathrm{C}=-28.4 \%$

SRR-471. Padang, $1 B, 1755$ to $1765 \mathrm{~cm}$

General Comment (RJM): SRR-469 to -471 represent a series of pollen assemblage changes which are thought to indicate vegetational changes in accordance with climatic amelioration of ca $2^{\circ} \mathrm{C}$. Timing of this change corresponds closely to similar climatically related changes in New Guinea and elsewhere (Flenley, 1980; Morley, 1980c).

\section{Lake Sipinggan series}

Organic detritus in sediment profile coll with Russian corer from Lake Sipinggan, volcanic crater lake at $1445 \mathrm{~m}$ alt near Lintongnihuta, Tapanuli, Sumatera Utara $\left(2^{\circ} 10^{\prime} \mathrm{N}, 98^{\circ} 50^{\prime} \mathrm{E}\right)$. $9.35 \mathrm{~m}$ organic deposit overlies rhyolitic tuff and quoted sample depth increments (in $\mathrm{m}$ ) refer to present water/mud interface. Coll 1974 and subm by B K Maloney, Univ Hull.

\section{SRR-1015. Lake Sipinggan, 2.7 to $2.8 \mathrm{~m}$} $1700 \pm 70$

Dates significant rise of herbaceous elements in pollen diagram.

SRR-1016. Lake Sipinggan, 5.7 to $5.8 \mathrm{~m}$

Dates end of major clearance phase.

SRR-1017. Lake Sipinggan, 7.6 to $7.7 \mathrm{~m}$

Dates beginning of major clearance phase.

SRR-1018. Lake Sipinggan, 8.1 to $8.2 \mathrm{~m}$

Dates end of swamp forest phase.

SRR-865. Lake Sipinggan, 9 to $9.1 \mathrm{~m}$

SRR-473. Lake Sipinggan, 9.15 to $9.22 \mathrm{~m}$

Dates base of core which was pollen analyzed.

$$
\begin{array}{r}
4460 \pm 50 \\
\delta^{1 s} C=-30.1 \% \\
9230 \pm \mathbf{3 0} \\
\delta^{1 s} C=-33.6 \% \%
\end{array}
$$

$10,950 \pm 90$ $\delta^{13} C=-31.3 \%$

$12,380 \pm 110$ $\delta^{13} C=-31.7 \%$

$12,120 \pm 140$ $\delta^{1 s} \mathrm{C}=-30.7 \%$

General Comment (BKM): series dates several significant vegetational changes, some attributable to man's activities and some due to hydroseral progression. SRR-865 appears anomalous in sequence, probably due to inwash of older material from crater sides. 


\section{Pea Sim-sim Swamp series}

Organic detritus in sediment profile coll with Russian corer from Pea Sim-sim Swamp, volcanic crater at $1450 \mathrm{~m}$ alt near Lintongnihuta, Tapanuli, Sumatera Utara $\left(2^{\circ} 10^{\prime} \mathrm{N}, 98^{\circ} 51^{\circ} \mathrm{E}\right)$. Quoted sample depths (in $\mathrm{m}$ ) refer to present water/mud interface. Coll 1974 and subm by B K Maloney.

\section{SRR-1019. Pea Sim-sim Swamp, 2.1 to $2.2 \mathrm{~m}$}

Dates rise of herbaceous elements.

$\begin{array}{ll}11,500 \pm 80 & \end{array}$

SRR-1020. Pea Sim-sim Swamp, 4.1 to $4.2 \mathrm{~m} \quad \delta^{13} C=-31.5 \%$ Dates beginning of major phase of dry land vegetation change.

\section{SRR-1021. Pea Sim-sim Swamp, 6.6 to $6.7 \mathrm{~m} \quad \delta^{13} C=-30.1 \%$}

Dates end of large rise in Cyathea spare percentages.

\section{SRR-864. Pea Sim-sim Swamp, 7.15 to $7.25 m$} Dates large rise in Cyathea spore percentages.

$$
16,210 \pm 160
$$

$\delta^{13} C=-29.1 \%$

$17,720 \pm 80$

SRR-1022. Pea Sim-sim Swamp, 8.15 to 8.25m $\delta^{13} C=-31.0 \%$ Dates significant dry land vegetation change.

\section{SRR-472. Pea Sim-sim Swamp, 9.66 to $9.76 \mathrm{~m}$}

Dates base of core which was pollen analyzed.

General Comment (BKM): series dates several significant vegetational changes, some attributable to man's activities. Appreciable decrease in sedimentation rate in upper part of core as suggested by SRR-1019 is confirmed by additional analyses at 1.9 to $2.1 \mathrm{~m}$ depth $(7280 \pm 150$; SR$517)$ and 2.3 to $2.5 \mathrm{~m}$ depth $(8230 \pm 150$; SR-518).

\section{H. Malaysia \\ SRR-467. Tasek Bera, 385 to $395 \mathrm{~cm}$

$$
660 \pm 80
$$$$
\delta^{13} \mathrm{C}=-28.8 \%
$$

Coarse detritus mud in core from Tasek Bera, Pahang, W Malaysia $\left(3^{\circ} 10^{\prime} \mathrm{N}, 102^{\circ} 44^{\prime} \mathrm{E}\right)$ alt $30 \mathrm{~m}$. Coll 1972 and subm by R J Morley. Comment (RJM): sample is from horizon just above level at which pollen of regrowth taxa show marked increase in abundance and at which sediment accumulation rates show distinct increase. This event is considered to mark time at which local population began extensive forest clearance, leading to soil erosion and more rapid deposition of sediment (Morley, 1980c).

\section{Storbreen (Site 1) series, South Norway \\ I. Norway}

Sphagnum peat in two layers, up to $2 \mathrm{~cm}$ thick and 15 to $20 \mathrm{~cm}$ apart, buried beneath outer moraine ridge at $1330 \mathrm{~m}$ alt on $\mathrm{N}$ flank of Stor- 
breen glacier foreland $\left(61^{\circ} 35^{\prime} \mathrm{N}, 8^{\circ} 20^{\prime} \mathrm{E}\right)$. Coll 1975 and subm by J A Matthews, Univ Edinburgh.

SRR-1083. Storbreen (Site 1)

Sample from upper peat layer.

\section{SRR-1084. Storbreen (Site 1)}

Sample from lower peat layer.

General Comment (JAM): end moraine ridge marks greatest extent of glacier in Neoglacial time. Samples are from folded continuous layers, ca $50 \mathrm{~cm}$ beneath surface of moraine on distal side. Dates indicate that glacier reached Neoglacial max in 'Little Ice Age'. A less well vegetated end moraine ridge, which has mostly enveloped the ridge, has been dated by lichenometry to ca AD 1750 (Matthews, 1974; 1975; 1977).

\section{SRR-1085. Storbreen (Site 2)}

$$
1070 \pm 40
$$$$
\delta^{13} C=-27.1 \%
$$

Podzol ( $A_{1}$ horizon) buried by outer moraine ridge at $1120 \mathrm{~m}$ alt (above tree line) on $\mathrm{N}$ flank of Storbreen glacier foreland $\left(61^{\circ} 35^{\prime} \mathrm{N}, 8^{\circ}\right.$ $20^{\prime}$ E). Coll 1975 and subm by J A Matthews. Comment (JAM): sample is from discontinuous layer, ca $40 \mathrm{~cm}$ beneath surface of moraine on distal side, in stratigraphy similar to SRR-1083. Date indicates that glacier reached Neoglacial max after $1000{ }^{14} \mathrm{C}$ yr BP, possibly in pre- 'Little Ice Age' times.

\section{Fugla Ness series}

\section{J. Scotland}

Wood from peat bed exposure on coast of Fugla Ness, N Shetland $\left(60^{\circ} 36^{\prime} \mathrm{N}, 1^{\circ} 25^{\prime} \mathrm{W}\right.$, Natl Grid Ref HU 311913$)$. Samples coll by various workers subm during 1975 by N R Page, Middlesex Polytechnic.

\section{SRR-490. Fugla Ness}

$$
\begin{array}{r}
\mathbf{3 8 , 9 8 0}+\mathbf{9 5 0} \\
\quad-\mathbf{8 5 0} \\
\delta^{13} C=-26.2 \%
\end{array}
$$

Whole wood (Pinus) coll 1974 by N R Page. Sample given min pretreatment, $i e$, fragmented and refluxed in distilled water for $48 \mathrm{hr}$.

\section{SRR-666. Fugla Ness}

$>\mathbf{3 3 , 3 0 0}$

$\mathrm{d}^{14} \mathrm{C}=-\mathbf{1 0 0 0 . 0} \pm \mathbf{4 . 0} \%$

Cellulose fraction isolated from wood sample previously dated at $40,100+2000 ;$ SRR-59.$$
+1270
$$$$
\mathbf{4 3 , 9 7 0}
$$

SRR-667. Fugla Ness$$
\delta^{1 s} C=-24.7 \%
$$

Cellulose fraction isolated from wood sample SRR-490.
} 
$\begin{array}{lr} & +1450 \\ \mathbf{4 4 , 9 7 0} & -\mathbf{1 2 3 0} \\ \text { SRR-758. Fugla Ness } & \delta^{13} C=-23.2 \% 0 \\ \text { Cellulose fraction isolated from wood (Erica) coll } 1967 \text { by D Flinn. }\end{array}$

General Comment: cellulose prepared for SRR-758 dated 47,500 $\begin{array}{r}+2900 \text {; } \\ -2100\end{array}$ GrN-7634 (W Mook, written commun).

\section{Dun Moss series}

Peat from $10 \mathrm{~m}$ profile coll using Russian borer from undisturbed ombrotrophic peat bog Dun Moss, Perthshire $\left(56^{\circ} 41^{\prime} \mathrm{N}, 3^{\circ} 22^{\prime} \mathrm{W}\right.$, Natl Grid Ref NO 168560 ). Quoted depth intervals (in $\mathrm{cm}$ ) relate to present bog surface. Coll 1973 and subm by J H Dickson and T Keatinge, Univ Glasgow.

\section{SRR-548. Dun Moss, 705 to $710 \mathrm{~cm}$}

$6140 \pm 120$

Peat composed mainly of $S p h a g n u m$ spp an dates alder rise.

\section{SRR-549. Dun Moss, 750 to $755 \mathrm{~cm}$}

Peat composed mainly $\delta^{13} \mathrm{C}=-24.9 \%$ (Paludella squarrosa, Calliergon $\mathrm{sp}$ ) datem spp with some rich mosses della squarrosa, in profle aludella squarrosa, in profile and change from fen peat to acid sphagnum peat.

SRR-550. Dun Moss, 790 to $795 \mathrm{~cm}$

$7040 \pm 100$

Peat composed mainly of Paludella squar nitens. Dates occurrence of Paludecium

$\begin{array}{ll}\mathbf{8 0 4 0} \pm 140 & \end{array}$

SRR-551. Dun Moss, 950 to $957 \mathrm{~cm} \quad \boldsymbol{\delta}^{13} \mathrm{C}=-26.5 \%$

Peat composed mainly of Sphagnum spp, Carex spp, and Paludella squarrosa, dates hazel rise.

\section{SRR-552. Dun Moss, 987 to $993 \mathrm{~cm}$}

$9020 \pm 150$

Peat composed mainly of Carex sp, dates earliest organic sediment in profile.

\section{Loch Pityoulish series}

Fine organic detritus in mud from bed of Loch Pityoulish, $2.5 \mathrm{~km}$ $\mathrm{NE}$ of Aviemore, Speyside $\left(57^{\circ} 12^{\prime} \mathrm{N}, 3^{\circ} 48^{\prime} \mathrm{W}\right.$, Natl Grid Ref NH (28) 923 138). Core taken under ca $20 \mathrm{~m}$ water column with Mackereth corer, sediment depth increments (in $\mathrm{cm}$ ) are quoted relative to mud/water interface. Coll 1974 and subm by P E O'Sullivan, Wolverhampton Poly-
technic. 


\section{SRR-589. Loch Pityoulish, 30 to $40 \mathrm{~cm}$}

SRR-588. Loch Pityoulish, 65 to $74 \mathrm{~cm}$

SRR-587. Loch Pityoulish, 130 to $140 \mathrm{~cm}$

SRR-586. Loch Pityoulish, 170 to $180 \mathrm{~cm}$

SRR-459. Loch Pityoulish, 214 to $226 \mathrm{~cm}$

SRR-460. Loch Pityoulish, 229 to $238 \mathrm{~cm}$

SRR-571. Loch Pityoulish, 246 to $256 \mathrm{~cm}$

SRR-572. Loch Pityoulish, 256 to $262 \mathrm{~cm}$ General Comment (PEO'S): pollen analysis in conjunction with these ages has been used to construct vegetational history of area surrounding loch for greater part of Flandrian time (O'Sullivan, 1976).

$$
\begin{array}{r}
\mathrm{d}^{14} \mathrm{C}=-\mathbf{9 9 8 . 4} \pm \mathbf{1 . 2 6} \% \\
\delta^{13} \mathrm{C}=-27.8 \%
\end{array}
$$

\section{SRR-595. Mintlaw}

Organic mud in stratified band up to $16 \mathrm{~cm}$ thick and overlain by ca $5 \mathrm{~m}$ stratified outwash at Mintlaw, Aberdeenshire $\left(57^{\circ} 30^{\prime} \mathrm{N}, 2^{\circ} 0^{\prime} \mathrm{W}\right)$. Coll 1974 by E A Fitzpatrick subm by A R Gunson, Univ Aberdeen. Comment (ARG): sec from which sample was taken contains no evidence for glacier ice at site. Therefore, age supports concept of unglaciated enclave during Late-Devensian glacial advance in N E Scotland.$$
+1030
$$$$
36,720
$$

SRR-596. Cruden Bay$$
\delta^{13} C=-26.8 \%
$$

Organic mud in stratified band up to $10 \mathrm{~cm}$ thick and overlain by ca $4 \mathrm{~m}$ clayey till at Cruden Bay, Aberdeenshire ( $\left.57^{\circ} 25^{\prime} \mathrm{N}, 1^{\circ} 51^{\prime} \mathrm{W}\right)$. Coll 1974 by E A Fitzpatrick; subm by A R Gunson. Comment (ARG): sample deposited before last glacial advance in coastal area of $\mathrm{E}$ Aberdeenshire and gives max age for advance.
}

\section{Robroyston series}

Biogenic deposit, mainly moss (Scorpidium Scorpioides) with small amounts of sedge, overlain by boulder clay in interdrumlin hollow at Robroyston, Glasgow ( $55^{\circ} 53^{\prime} \mathrm{N}, 4^{\circ} 12^{\prime} \mathrm{W}$, Natl Grid Ref NS 633676). Quoted sample depth increments (in $\mathrm{cm}$ ) relate to ground surface. Coll 1975 and subm by J H Dickson. 


\section{SRR-696. Robroyston, 33 to $36 \mathrm{~cm}$}

SRR-697. Robroyston, 41 to $43 \mathrm{~cm}$
$11,650 \pm 190$ $\delta^{13} \mathrm{C}=-27.8 \%$

$11,270 \pm 130$ $\delta^{13} C=-29.4 \%$

\section{Springburn series}

Peat from bench sec cut into drumlin at Springburn, Glasgow $\left(55^{\circ}\right.$ $53^{\prime} \mathrm{N}, 4^{\circ} 12^{\prime} \mathrm{W}$, Natl Grid Ref NS 609678 ). Two peat bands occur in profile; one (lateglacial) immediately underlies till deposit at ca 1.73 to $6.25 \mathrm{~m}$ depth, the other (postglacial) overlies but is separated from upper till horizon by ca $7 \mathrm{~cm}$-thick deposit of silt/clay. Coll 1975 and subm by R J Price, Univ Glasgow.

SRR-760. Springburn (postglacial)

$6000 \pm 50$

Upper peat layer, ca $21 \mathrm{~cm}$ thick, overlain by ca $0.55 \mathrm{~m}$ sand $/$ silt and $0.9 \mathrm{~m}$ till.

\section{SRR-761. Springburn (lateglacial)}

$11,140 \pm 110$

Lower peat layer, ca $25 \mathrm{~cm}$ thick, overlies sand and gravel deposits.

\section{Ben Arkle series}

Peat in fragmented layer buried by ca $1 \mathrm{~m}$ sand and gravels of solifluction terrace, near summit of Ben Arkle, Sutherland $\left(58^{\circ} 25^{\prime} \mathrm{N}, 4^{\circ} 50^{\prime}\right.$ E, Natl Grid Ref NC 312452). Quoted sample depths (in $\mathrm{m}$ ) relate to distance upslope from terminus of solifluction terrace. Coll 1975 and subm by $\mathrm{D}$ N Mottershead, Portsmouth Polytechnic.

SRR-722. Ben Arkle, $2 \mathrm{~m}$

SRR-723. Ben Arkle, 10m

Sample at top of lens, ca $60 \mathrm{~cm}$ thick.

\section{SRR-724. Ben Arkle, 10m}

Sample at base of lens, ca $60 \mathrm{~cm}$ thick.

SRR-725. Ben Arkle, 13m $\mathbf{4 7 3 0} \pm \mathbf{5 0}$ $\delta^{13} C=-27.0 \%$

$\mathbf{3 9 9 0} \pm \mathbf{5 0}$ $\delta^{13} \mathrm{C}=-27.2 \%$ $\mathbf{5 4 4 0} \pm \mathbf{6 0}$
$\delta^{13} \mathrm{C}=-27.5 \%$

$$
5200 \pm 60
$$

$\delta^{13} C=-27.0 \%$

General Comment (DNM): stratigraphic relationships and measured ages suggest that buried peat was small mire that developed in an upland hollow between 5500 and 4000 BP. It was apparently rapidly over-run by solifluction assoc with deteriorating climatic conditions of Sub-Atlantic phase. This suggests that solifluction movement may be extremely limited at present time.

\section{SRR-756. Lochwinnoch Gap}

$11,210 \pm 190$

flo floor of Lochwinnoch Gap, breached watershed with wide flat floor at 
ca $30 \mathrm{~m}$ OD, Renfrewshire $\left(55^{\circ} 50^{\prime} \mathrm{N}, 4^{\circ} 35^{\prime} \mathrm{W}\right.$, Natl Grid Ref NS 339 556). Coll 1974 by R Ward subm by R J Price.

\section{Lochan Doilead series}

Organic detritus in sediment cores, coll using $7.5 \mathrm{~cm}$ diam Livingstone piston corer, from marginal fen at Lochan Doilead, Inverness $\left(56^{\circ} 59^{\prime} \mathrm{N}\right.$, $5^{\circ} 48^{\prime}$ W, Natl Grid Ref 17/676946). Quoted sample depth increments (in $\mathrm{cm}$ ) relate to present surface. Coll 1972 and subm by H J B Birks and W Williams, Univ Cambridge.

SRR-764. Lochan Doilead, 147.5 to $152.5 \mathrm{~cm}$

SRR-765. Lochan Doilead, 243.5 to $246.5 \mathrm{~cm}$

SRR-766. Lochan Doilead, 342.1 to $347.8 \mathrm{~cm}$ Increase in Quercus pollen.

SRR-767. Lochan Doilead, 440 to $445 \mathrm{~cm}$

SRR-768. Lochan Doilead, 572.5 to $577.5 \mathrm{~cm}$ Decrease in Ulmus pollen.

SRR-769. Lochan Doilead, 672.5 to $677.5 \mathrm{~cm}$ Increase in Quercus pollen.

SRR-770. Lochan Doilead, 705 to $710 \mathrm{~cm}$ Rise in Alnus pollen.

SRR-771. Lochan Doilead, 762.5 to $767.5 \mathrm{~cm}$ Rise in Pinus pollen.

SRR-772. Lochan Doilead, 799 to $805 \mathrm{~cm}$ Rise in Corylus pollen.

SRR-773. Lochan Doilead, 809 to $816 \mathrm{~cm}$ Peak of Juniperus pollen.

SRR-774. Lochan Doilead, 825 to $835 \mathrm{~cm}$ Rise in Betula pollen.

SRR-775. Lochan Doilead, 880 to $890 \mathrm{~cm}$ Lowest pollen bearing sediment at site.

$$
\begin{array}{r}
1980 \pm \mathbf{5 0} \\
\delta^{13} C=-29.4 \% 0 \\
\mathbf{2 4 6 0} \pm \mathbf{7 0} \\
\delta^{13} C=-28.5 \% \\
\mathbf{3 6 0 0} \pm \mathbf{6 0} \\
\delta^{13} C=-27.3 \% \text { o }
\end{array}
$$

$$
\begin{array}{r}
\mathbf{4 1 0 0} \pm \mathbf{9 0} \\
\delta^{1 s} C=-28.1 \% 0 \\
\mathbf{4 5 9 0} \pm \mathbf{6 0} \\
\delta^{13} C=-28.8 \% \circ
\end{array}
$$

$$
5750 \pm 80
$$$$
\delta^{13} C=-29.7 \% \text { 。 }
$$

$$
\begin{array}{r}
6180 \pm 90 \\
\delta^{1 s} C=-30.2 \%
\end{array}
$$

$$
7870 \pm 130
$$$$
\delta^{1 s} C=-21.0 \%
$$

$$
9280 \pm 120
$$$$
\delta^{13} \mathrm{C}=-28.1 \%
$$

$10,200 \pm 150$

$\delta^{13} C=-29.5 \%$

$10,280 \pm 120$ $\delta^{13} \mathrm{C}=-24.9 \%$

$11,990 \pm 140$ $\delta^{13} C=-23.2 \%$

General Comment (HJB/WW): dates are inherently consistent with dates for comparable pollen stratigraphic changes at nearby Loch Meodal in Sleat Peninsula of Isle of Skye. 


\section{An Druim series}

Detritus lake mud in core coll with $5 \mathrm{~cm}$ diam Livingstone corer from An Druim, Loch Eriboll, W Sutherland (58 $28^{\prime}$ N, $4^{\circ} 42^{\prime}$ W, Natl Grid Ref 29/436568). Quoted sample depth increments (in $\mathrm{cm}$ ) relate to mud surface. Coll 1973 and subm by H J B Birks, W Williams and Hilary H Birks.

SRR-776. An Druim, 247.5 to $252.5 \mathrm{~cm}$

SRR-866. An Druim, 252.5 to 257.5cm

SRR-777. An Druim, 347.5 to $352.5 \mathrm{~cm}$

SRR-778. An Druim, 447.5 to $452.5 \mathrm{~cm}$

SRR-779. An Druim, 522.5 to $527.5 \mathrm{~cm}$

SRR-780. An Druim, 622 to $628 \mathrm{~cm}$

$$
\begin{array}{r}
1630 \pm \mathbf{6 0} \\
\delta^{13} C=-29.0 \% \\
\mathbf{9 1 0} \pm \mathbf{6 0} \\
\delta^{13} C=-29.7 \% \\
1320 \pm \mathbf{7 0} \\
\delta^{13} C=-29.7 \% \\
\mathbf{2 2 8 0} \pm \mathbf{6 0} \\
\delta^{13} C=-30.7 \% \\
\mathbf{2 7 3 0} \pm \mathbf{7 0} \\
\delta^{13} C=-30.2 \% \\
\mathbf{3 5 6 0} \pm \mathbf{7 0} \\
\delta^{13} C=-30.4 \% \circ \\
\mathbf{5 7 4 0} \pm \mathbf{8 0} \\
\delta^{13} C=-30.8 \% \circ
\end{array}
$$

Expansion of Alnus pollen and decrease in Ulmus pollen.

\section{SRR-782. An Druim, 784 to $791 \mathrm{~cm}$}

$10,070 \pm 70$

Expansion of Corylus pollen and decrease in Juniperus pollen.

SRR-783. An Druim, 807.5 to 817.5cm

$10,650 \pm 110$

Expansion of Betula and Juniperus pollen.

SRR-784. An Druim, 837.5 to 847.5cm

Expansion of non-tree pollen decrease in tree pollen.

$$
11,720 \pm 130
$$$$
\delta^{13} \mathrm{C}=-26.4 \%
$$

\section{SRR-785. An Druim, 870 to $880 \mathrm{~cm}$}

$12,490 \pm 150$

Base of polleniferous sequence at site.

General Comment (HJB/WW): possibility of hard-water error in dates cannot be discounted as site is near outcrops of Durness limestone. SRR781 to -785 may, by comparison with dated pollen sequences elsewhere in N W Scotland, be ca $700 \mathrm{yr}$ too old. Despite this, SRR-781 provides very young date for expansion of Alnus; SRR-866 was measured to check significance of age obtained for SRR-776. Upper sediments may be disturbed by soil inwashing, erosion, etc, resulting from human activities. 


\section{Loch Ashik series}

Organic detritus in core, taken with $7.5 \mathrm{~cm}$ diam Livingstone corer, from marginal fen of Loch Ashik, Isle of Skye $\left(57^{\circ} 15^{\prime} \mathrm{N}, 5^{\circ} 49^{\prime} \mathrm{W}\right.$, Natl Grid Ref 18/688232). Quoted depth increments (in $\mathrm{cm}$ ) relate to present mud surface. Coll 1975 by W Willams, H J B Birks, B Huntley, and A R Hall, Univ Cambridge; subm by W Williams and $\mathrm{H}$ J B Birks.

SRR-804. Loch Ashik, 143.5 to $146.5 \mathrm{~cm}$

SRR-805. Loch Ashik, 193.5 to $196.5 \mathrm{~cm}$

Dates decrease in pine pollen.

SRR-806. Loch Ashik, 208.5 to $211.5 \mathrm{~cm}$

Dates local increase in pine pollen.

SRR-807. Loch Ashik, 233.5 to $236.5 \mathrm{~cm}$

Dates decrease in elm pollen.

SRR-808. Loch Ashik, 282.5 to $287.5 \mathrm{~cm}$

Dates increase in alder pollen.

SRR-809. Loch Ashik, 325 to $330 \mathrm{~cm}$

Dates regional increase in pine pollen.

SRR-810. Loch Ashik, 382.5 to $387.5 \mathrm{~cm}$

Dates increase in oak pollen.

SRR-811. Loch Ashik, 435 to $440 \mathrm{~cm}$

Dates increase in hazel pollen.

SRR-812. Loch Ashik, 462.5 to $467.5 \mathrm{~cm}$

Dates increase in birch pollen.

SRR-813. Loch Ashik, 472.5 to $477.5 \mathrm{~cm}$

Dates increase in Juniper pollen.

$$
\begin{array}{r}
\mathbf{2 7 0 0} \pm \mathbf{6 0} \\
\delta^{1 s} C=-27.1 \% o \\
\mathbf{3 9 5 0} \pm \mathbf{7 0} \\
\delta^{18} C=-27.4 \% o
\end{array}
$$

$$
4150 \pm 70
$$$$
\delta^{13} C=-26.9 \%
$$

$$
4530 \pm 70
$$

$\delta^{1 s} C=-27.2 \%$

$$
\begin{array}{r}
\mathbf{6 3 6 0} \pm \mathbf{8 0} \\
\delta^{1 s} C=-27.6 \%
\end{array}
$$$$
\begin{array}{r}
\mathbf{7 4 7 0} \pm \mathbf{7 0} \\
\delta^{13} C=-26.8 \%
\end{array}
$$

$$
\mathbf{8 3 2 0} \pm \mathbf{8 0}
$$

$\delta^{13} C=-27.0 \%$

$$
\begin{array}{r}
9540 \pm 70 \\
\delta^{1 s} C=-26.7 \% o
\end{array}
$$

$$
\mathbf{1 0 , 0 9 0} \pm 90
$$$$
\delta^{13} C=-22.4 \%
$$

$$
10,330 \pm 80
$$

$\delta^{13} C=-20.0 \%$

General Comment (HW/HJBB): dates provide consistent chronology for major changes in pollen stratigraphy and demonstrate early expansion of hazel pollen, as elsewhere on Skye, and short-lived expansion and subsequent decline of pine at ca 4000 BP as elsewhere in N W Scotland. Ages provide valuable comparison with dated profiles from sites on adjacent mainland of Scotland and on Skye.

\section{Loch Cleat series}

Detritus mud and/or silt in $5 \mathrm{~cm}$ diam core taken from marginal fen of Loch Cleat, Isle of Skye $\left(57^{\circ} 41^{\prime} \mathrm{N}, 6^{\circ} 20^{\prime} \mathrm{W}\right.$, Natl Grid Ref $18 / 415$ 
743). Quoted sample depth increments (in $\mathrm{cm}$ ) relate to present surface. Coll 1973 by H J B Birks and subm by W Williams.

\section{SRR-932. Loch Cleat, 247.5 to $252.5 \mathrm{~cm}$}

SRR-933. Loch Cleat, 357.5 to $362.5 \mathrm{~cm}$

SRR-934. Loch Cleat, 467.5 to $472.5 \mathrm{~cm}$

SRR-935. Loch Cleat, 627.5 to $632.5 \mathrm{~cm}$

SRR-936. Loch Cleat, 725 to $730 \mathrm{~cm}$

SRR-937. Loch Cleat, 787.5 to $792.5 \mathrm{~cm}$

SRR-938. Loch Cleat, 847.5 to $852.5 \mathrm{~cm}$

SRR-939. Loch Cleat, 872.5 to $877.5 \mathrm{~cm}$

SRR-940. Loch Cleat, 893 to $900 \mathrm{~cm}$

SRR-941. Loch Cleat, 922.5 to $929 \mathrm{~cm}$

$$
\begin{array}{r}
1750 \pm 60 \\
\delta^{1 s} C=-27.8 \% \\
\mathbf{2 5 3 0} \pm \mathbf{7 0} \\
\delta^{13} C=-27.9 \% \\
\mathbf{3 1 0 0 \pm 6 0 0} \\
\delta^{13} C=-28.3 \%
\end{array}
$$

$\mathbf{4 8 4 0} \pm 90$

$6590 \pm 80$ $\delta^{13} C=-29.5 \%$

$8080 \pm 90$ $\delta^{1 s} C=-29.1 \%$

$9000 \pm 100$ $\delta^{13} C=-26.3 \%$

$9760 \pm 150$ $\delta^{13} C=-21.1 \%$

$9990 \pm 130$ $\delta^{13} C=-21.7 \%$

$10,470 \pm 180$ $\delta^{13} \mathrm{C}=-26.4 \%$

General Comment (HJBB): the ten dates are consistent within themselves and provide site chronology, estimates of sediment accumulation rates, and dates for major changes in pollen stratigraphy. Dates agree with those elsewhere in N Skye. Spread of birch and hazel scrub are dated by SRR-940 and -939 between $9760 \pm 150$ and $9990 \pm 130$ BP. Onset of local extensive clearance of this scrub and development of pastoral and arable agriculture are dated by SRR-935 to $4840 \pm 90 \mathrm{BP}$ (Williams, 1977).

\section{SRR-869. Montrose Basin}

$7340 \pm 80$

Peat from base of lower of two layers exposed in bluff behind foreshore near Maryton at $\mathrm{W}$ end of Montrose Basin $\left(56^{\circ} 42^{\prime} \mathrm{N}, 2^{\circ} 31^{\prime} \mathrm{W}\right.$, Natl Grid Ref 6838 5650). Exposure shows $0.85 \mathrm{~m}$ silty (carse) clay overlying $0.1 \mathrm{~m}$ silty peat which overlies $0.18 \mathrm{~m}$ gray micaceous fine sand overlying $0.15 \mathrm{~m}$ fibrous peat. Below basal peat lies $0.05 \mathrm{~m}$ laminated gray silt resting on red/brown silty clay. Coll 1975 by $\mathrm{R}$ A Cullingford, Univ Exeter and D E Smith, Lanchester Polytechnic, Coventry; subm by R L Jones, Lanchester Polytechnic. Comment (RLJ): age confirms middle Flandrian pollen spectra from deposit but suggests major hiatus between $* \delta^{13} \mathrm{C}$ denotes estimate of stable isotope enrichment. 
underlying late glacial marine clay and inception of peat formation preceding Carse transgression in area.

Bore hole (No. SLN 33) series, North Sea

Non-calcareous carbon (2M HCl resistant) in marine sediment core from bore hole (SLN 33) between Forties and Claymore oil fields (within UK license block $15 / 28$ at $58^{\circ} 4^{\prime} \mathrm{N}, 0^{\circ} 34^{\prime} \mathrm{E}$ ). Core taken from center of seabed pockmark overlain by $155 \mathrm{~m}$ water column. Quoted sample depths (in $\mathrm{m}$ ) relate to present sea floor. Drilling operations were carried out from MV Wimpey Sealab Oct 1975. Samples subm by D Evans and N Fannin, Inst Geol Sci, Edinburgh.

SRR-903. (SLN 33), 11.15 to $11.30 \mathrm{~m}$ ${ }^{*} \delta^{13} C=-25.0 \pm 2.0 \%$

$$
\begin{array}{r}
\mathbf{3 3 , 8 9 0}+\mathbf{1 0 1 0} \\
-\mathbf{9 0 0} \\
\delta^{13} C=-26.4 \% 0 \\
+\mathbf{9 7 0} \\
\mathbf{3 3 , 3 9 0}
\end{array}
$$

SRR-904. (SLN 33), 36.10 to $36.25 m$

$-870$

SRR-905. (SLN 33), 51.92 to $52.04 \mathrm{~m}$ ${ }^{*} \delta^{13} \mathrm{C}=-25.0 \pm 2.0 \%$

$$
\begin{array}{r}
\mathbf{3 4 , 7 9 0}-\mathbf{9 6 0} \\
\delta^{13} C=-26.4 \% \\
+\mathbf{7 4 0} \\
\mathbf{3 4 , 4 2 0}-\mathbf{6 8 0}
\end{array}
$$$$
+1090
$$

SRR-906. (SLN 33), 67.55 to $67.65 m$

SRR-907. (SLN 33), 85.67 to 85.83m

$$
\begin{array}{r}
{ }^{*} \delta^{13} C=-25.0 \pm 2.0 \% \\
+\mathbf{8 4 0} \\
\mathbf{3 1 , 9 8 0}-\mathbf{7 6 0}
\end{array}
$$

SRR-908. (SLN 33), 115.32 to $115.44 m{ }^{*} \delta^{13} C=-25.0 \pm 2.0 \%$ o

$$
32,980+710
$$

SRR-909. (SLN 33), 180.86 to $\mathbf{1 8 0 . 9 5 m} \quad \delta^{1 s} C=-24.7 \%$ 。 General Comment: bio-and climatostratigraphy of these sediments is discussed in Harland et al, 1978.

$* \delta^{13} \mathrm{C}$ denotes estimate of stable isotope enrichment. 


\section{Inchinnan series}

Marine shells and organic detritus in deposits exposed during excavation of sewer trench at Inchinnan, Renfrew ( $\left.55^{\circ} 54^{\prime} \mathrm{N}, 4^{\circ} 26^{\prime} \mathrm{W}\right)$. Marine deposits range in alt between $+0.7 \mathrm{~m}$ and $\mathrm{ca}+19 \mathrm{~m}$ OD and from low ground pass upward through littoral deposits and possible estuarine clays and silts to shelly marine silts ca $2 \mathrm{~m}$ thick on high ground. Coll 1975 by R Ward and M A E Browne; subm by M A E Browne, Inst Geol Sci, Edinburgh.

SRR-923. Inchinnan, $+\mathbf{0 . 7 m}$ OD

(a) 'Outer' carbonate

(b) 'Inner' carbonate

$$
\begin{array}{r}
\mathbf{1 2 , 2 9 0} \pm \mathbf{3 1 0} \\
\delta^{13} C=+1.5 \% \text { o } \\
+\mathbf{6 3 0} \\
\mathbf{1 4 , 3 5 0} \\
-\mathbf{5 8 0} \\
\delta^{13} C=+1.4 \% \text { o }
\end{array}
$$

Arctica islandica at base of lateglacial sand (Modiolus bed) ca $1 \mathrm{~m}$ thick and overlain by brown clay $400 \mathrm{~m}$ NNW of Garnieland Farm (Natl Grid Ref NS 4805 7014).

SRR-924. Inchinnan, + 0.7 m OD

$$
\begin{aligned}
& 13,080 \pm 150 \\
& \delta^{13} C=-3.0 \% \\
& 12,460 \pm 280 \\
& \delta^{13} C=+1.3 \% 0
\end{aligned}
$$

Modiolus modiolus at base of lateglacial sand bed $400 \mathrm{~m}$ NNW of Garnieland Farm.

SRR-925. Inchinnan, +6.1m OD

(a) 'Outer' carbonate

$13,490 \pm 330$

(b) 'Inner' carbonate

$$
\delta^{13} C=+2.8 \%
$$

$\mathbf{1 3 , 5 0 0} \pm \mathbf{2 7 0}$ $\delta^{13} C=+1.4 \%$

Arctica islandica at base of shell bed $600 \mathrm{~m} \mathrm{SW}$ of Garnieland Farm (Natl Grid Ref NS 4768 6940).

SRR-926. Inchinnan, +6.1m OD

(a) 'Outer' carbonate

$$
12,390 \pm 110
$$$$
\delta^{13} C=+0.3 \% \text { 。 }
$$

(b) 'Inner' carbonate

$$
12,330 \pm 110
$$$$
\delta^{13} C=+0.3 \% \text { o }
$$

Modiolus modiolus at base of shell bed $600 \mathrm{~m}$ SW of Garnieland Farm.

SRR-949. Inchinnan, +12m OD

$15,380 \pm 110$

$\delta^{13} C=-25.0 \%$ 。

Sandy silt with plant debris at $2.7 \mathrm{~m}$ depth overlying shallow water and possible littoral, deposits $650 \mathrm{~m}$ SW of Garnieland Farm (Natl Grid Ref NS 4763 6932). 
SRR-927. Inchinnan, +11.5 to $+11.7 \mathrm{~m}$ OD

(a) 'Outer' carbonate

(b) 'Inner' carbonate
$12,700 \pm 100$ $\delta^{13} \mathrm{C}=+0.8 \%$ 。

$12,920 \pm 130$ $\delta^{13} C=-0.1 \%$

Arctica islandica at base of shelly marine silt (Clyde beds) ca $2 \mathrm{~m}$ thick, 500m ESE of Turnyland (Natl Grid Ref NS 4708 6922).

General Comment (MAEB): marine shell ages, when adjusted for 'apparent age' $(400 \pm 40 \mathrm{yr})$ suggest that Paisley-Renfrew area was deglaciated before 13,100 вP (SRR-925). Younger min age of ca 12,000 вP (SRR926) is explained by fact that this sp (Modiolus modiolus) is epifaunal and was living on foundation of gravel containing already sub-fossil Arctica shells (Browne et al, 1977). SRR-949 is much too old; silt probably contaminated by older reworked carbon.

\section{Netherton series}

Peat exposed in temporary sec $350 \mathrm{~m} \mathrm{E}$ of Netherton, Perthshire $\left(56^{\circ} 36^{\prime} \mathrm{N}, 3^{\circ} 12^{\prime} \mathrm{W}\right.$, Natl Grid Ref NO 26754605$)$. Peat occurs in two well-defined bands; uppermost (ca $0.08 \mathrm{~m}$ thick) deposit overlain by $0.9 \mathrm{~m}$ surface sand/gravel is separated from lower (ca $0.6 \mathrm{~m}$ thick) deposit by $0.3 \mathrm{~m}$ clay. Coll 1975 and subm by I B Paterson, Inst Geol Sci, Edinburgh.

\section{SRR-950. Netherton 1}

Upper peat deposit.

\section{SRR-951. Netherton 2}

Top $5 \mathrm{~cm}$ of lower peat deposit.

\section{SRR-952. Netherton 3}

Basal $5 \mathrm{~cm}$ of lower peat deposit.

\section{SRR-953. Shandford}

Peat at base of layer, ca $0.46 \mathrm{~m}$ thick, overlain by $0.46 \mathrm{~m}$ gray silt and resting on sand/gravel deposits $1.05 \mathrm{~km} \mathrm{SE}$ of Shandford, Perthshire $\left(56^{\circ}\right.$ $45^{\prime}$ N, $3^{\circ} 49^{\prime}$ W, Natl Grid Ref NO 4982 6202). Coll 1975 and subm by I B Paterson.

\section{SRR-954. South Ardittie}

$11,240 \pm 50$ $\delta^{13} C=-31.6 \%$ o

Sub-carse peat exposed in temporary sec $300 \mathrm{~m}$ ENE of South Ardittie, Perthshire (56 $27^{\prime}$ N, 30 $36^{\circ}$ W, Natl Grid Ref NO 0193 2835). Coll 1975 and subm by I B Paterson.

\section{Glim's Moss series}

Peat in core from Glim's Moss, Birsay, Mainland Orkney $\left(59^{\circ} 5^{\prime} \mathrm{N}\right.$, $3^{\circ} 13^{\prime} \mathrm{W}$, Natl Grid Ref HY 311 228). Quoted sample depths (in $\mathrm{cm}$ ) relate to present bog surface. Coll 1973 and subm by J H Dickson.

$* \delta^{13} \mathrm{C}$ denotes assumed value. 
SRR-973. Glim's Moss, 225 to $232 \mathrm{~cm}$

Dates rise of Calluna in pollen diagrams.

SRR-974. Glim's Moss, 288 to $295 \mathrm{~cm}$

Dates pollen evidence for transition from fen to bog peat.

SRR-975. Glim's Moss, 369 to $376 \mathrm{~cm}$

Dates end of high Plantage lanceolata phase in pollen diagram.

\section{SRR-976. Glim's Moss, 501 to $508 \mathrm{~cm}$}

$2150 \pm 70$

$\delta^{13} C=-27.5 \%$

$2090 \pm 60$

${ }^{13} \mathrm{C}=-28.4 \%$

$\mathbf{2 8 9 0} \pm \mathbf{7 0}$

$\delta^{13} C=-26.7 \%$ o

$5680 \pm 60$ $\delta^{13} C=-28.4 \%$

General Comment: site lies close to extensive areas of blanket peat which have developed on hills running $\mathrm{N}$ to $\mathrm{S}$ down Mainland Orkney. Four peat deposits in parish of Birsay (Glim's Moss, Burn of Rusht, Mid Hill, and Braes of Aglath) were studied for time and events involved in initiation of this major vegetational change (Keatinge and Dickson, 1979).

\section{SRR-981. Mid Hill, $130 \mathrm{~cm}$}

$3420 \pm 50$

Well-humified peat at base of blanket deposit Mid Hill, Birsay, Orkney $\left(59^{\circ} 6^{\prime} \mathrm{N}, 3^{\circ} 10^{\prime} \mathrm{W}\right.$, Natl Grid Ref HY 339 239). Coll 1975 and subm by J $\mathrm{H}$ Dickson.

\section{SRR-982. Burn of Rusht, $130 \mathrm{~cm}$}

$3360 \pm 50$

Well-humified peat at base of blanket deposit Burn of Rusht, Birsay, Orkney (59 $5^{\circ}$ N, $3^{\circ} 11^{\prime}$ W, Natl Grid Ref HY 330 217). Coll 1975 and subm by J H Dickson.

\section{SRR-983. Braes of Aglath, 150cm}

$$
\begin{array}{r}
\mathbf{2 9 2 0} \pm \mathbf{5 0} \\
\delta^{13} C=-28.7 \% \text { o }
\end{array}
$$

Well-humified peat at base of blanket deposit Braes of Aglath, Birsay, Orkney (59 $3^{\prime} \mathrm{N}, 3^{\circ} 8^{\prime} \mathrm{W}$, Natl Grid Ref HY 354 182). Coll 1974 and subm by J H Dickson.

\section{SRR-984. Dubh Lochan, 6m}

$9360 \pm 70$

$\delta^{1 s} C=-26.0 \%$

Diatomaceous lake mud in core from overgrown margin of Dubh Lochan, Rowardennan ( $56^{\circ} 9^{\prime} \mathrm{N}, 4^{\circ} 36^{\prime} \mathrm{W}$, Natl Grid Ref NS 378 965). Sample at base of lake sediment, ca $3 \mathrm{~m}$ thick, overlying clay and overlain by ca $3 \mathrm{~m}$ peat. Coll 1975 and subm by J H Dickson.

\section{SRR-985. Fin Glen, 189 to $191 \mathrm{~cm}$}

$6200 \pm 50$

Peat near base of deposit, ca $2 \mathrm{~m}$ thick, overlying boulder clay Fin Glen, Campsie Fells $\left(56^{\circ} 10^{\prime} \mathrm{N}, 4^{\circ} 16^{\prime} \mathrm{W}\right.$, Natl Grid Ref NS 586 832). Coll 1975 and subm by J H Dickson. 
SRR-989. Pleahillock

$4790 \pm 220$

Cellulose isolated from wood fragments buried in laminated clay infill of kettlehole $150 \mathrm{~m}$ SE of Pleahillock $\left(56^{\circ} 33^{\prime} \mathrm{N}, 3^{\circ} 22^{\prime} \mathrm{W}\right.$, Natl Grid Ref NO 1622 4106). Coll 1975 and subm by I B Paterson.

SRR-990. Mill of Pert

$7950 \pm 80$

$\delta^{1 s} \mathrm{C}=-25.4 \%$

Cellulose isolated from wood fragment at base of ca $2 \mathrm{~m}$ sand fill of erosion channel $630 \mathrm{~m}$ WSW of Mill of Pert $\left(56^{\circ} 47^{\prime} \mathrm{N}, 3^{\circ} 36^{\prime} \mathrm{W}\right.$, Natl Grid Ref NO 6439 6623). Coll 1975 and subm by I B Paterson.

\section{Cromarty Firth Crossing series}

Plant debris and marine shells from bore hole (No. C2) at $-1.8 \mathrm{~m}$ OD, Cromarty Firth Crossing ( $57^{\circ} 38^{\prime} \mathrm{N}, 4^{\circ} 22^{\prime} \mathrm{W}$, Natl Grid Ref NH 5879 6154). Quoted sample depth increments (in $\mathrm{m}$ ) relate to present surface. Coll 1975 and subm by J D Peacock, Inst Geol Sci, Edinburgh.

SRR-1068. Cromarty Firth Crossing, 13.5 to $13.96 \mathrm{~m}$

$\mathbf{8 7 5 0} \pm \mathbf{8 0}$
$\delta^{1 s} C=-28.2 \%$

Organic debris, possible composite of both marine and terrestrial plant material.

SRR-1069. Cromarty Firth Crossing, 18 to $18.46 m$

$$
7330 \pm 360
$$$$
\delta^{13} C=-0.3 \% \text { o }
$$

Marine shells (Littorina littorea).

SRR-1070. Cromarty Firth Crossing, 21.5 to $21.96 \mathrm{~m}$

$$
\begin{array}{r}
8160 \pm 150 \\
\delta^{1 s} C=+0.9 \% \text { o }
\end{array}
$$

Marine shells (Corbula gibba).

General Comment (JDP): dates confirm postglacial age inferred from lithology and palaeontology for this part of sequence. Marine shell ages (SRR-1069 and -1070) are in general agreement but are probably too low. Though shells appeared fresh, they may have been affected by post-retrieval chemical changes in clay. SRR-1068 is considered more reliable.

\section{Loch Salen series}

Detrital lake mud in Livingstone core coll from marginal fen of Loch Salen, Ardnamurchan $\left(56^{\circ} 43^{\prime}\right.$ N, $5^{\circ} 47^{\prime}$ W, Natl Grid Ref $17 / 693$ 653 ). Quoted sample depth increments (in $\mathrm{cm}$ ) relate to present mud surface. Coll 1975 by H J B Birks, W Williams, B Huntley, and A R Hall; subm by H J B Birks and W Williams.
SRR-1177. Loch Salen, 322 to $328 \mathrm{~cm}$
$430 \pm 40$
$\delta^{13} \mathrm{C}=-28.5 \%$
$940 \pm 40$
SRR-1178. Loch Salen, 522.5 to $527.5 \mathrm{~cm}$
$\delta^{13} C=-28.6 \%$

Dates lithologic change in profile. 
SRR-1179. Loch Salen, 715 to $720 \mathrm{~cm}$

Dates lithologic change in profile.

SRR-1180. Loch Salen, 775 to $780 \mathrm{~cm}$

Dates lithologic change in profile.

SRR-1181. Loch Salen, 968 to $972 \mathrm{~cm}$

Dates decrease in percentage Ulmus pollen.

SRR-1182. Loch Salen, 1007.5 to $1012.5 \mathrm{~cm}$

Dates decrease in percentage Ulmus pollen.

SRR-1183. Loch Salen, 1127.5 to $1132.5 \mathrm{~cm}$

Dates highest percentage of $A$ lnus pollen.

SRR-1184. Loch Salen, 1167.5 to $1172.5 \mathrm{~cm}$

Dates increase in percentage Alnus pollen.

SRR-1185. Loch Salen, 1237.5 to $1242.5 \mathrm{~cm}$

Dates increase in percentage Betula and Corylus pollen.

\section{SRR-1186. Loch Salen, 1242 to $1248 \mathrm{~cm}$}

Dates peak in percentage Juniperus pollen.

$$
\begin{array}{r}
\mathbf{2 7 2 0} \pm \mathbf{4 0} \\
\delta^{1 s} C=-28.6 \% \\
\mathbf{2 5 9 0} \pm \mathbf{4 0} \\
\delta^{1 s} C=-28.9 \% \\
\\
\mathbf{5 8 2 0} \pm \mathbf{4 0} \\
\delta^{13} C=-28.9 \% 0
\end{array}
$$

$$
6040 \pm 40
$$

$8^{15} \mathrm{C}=-28.8 \%$

$$
5880 \pm 40
$$$$
\delta^{13} \mathrm{C}=-28.1 \%
$$

$$
6280 \pm 40
$$$$
\delta^{15} \mathrm{C}=-28.4 \%
$$

$$
9480 \pm 70
$$

$\delta^{1 s} C=-27.7 \%$

$10,090 \pm 100$ $\delta^{13} \mathrm{C}=-24.9 \%$

General Comment (WW): age reversals between 720 to $780 \mathrm{~cm}$ and 1000 to $1130 \mathrm{~cm}$ depth correlate with increases in coarse organic component of sediment. This is considered to reflect two separate periods of much increased inwash of organic debris to lacustrine depositional environment due to marginal erosion from very steep sides of loch. Associated pollen curves are less smooth than those obtained for other Scottish sites and this is probably also due to erosion and inwash.

\section{Loch of Skaill series}

Lake mud in core from Loch of Skaill, Orkney $\left(59^{\circ} 3^{\prime} \mathrm{N}, 3^{\circ} 20^{\prime} \mathrm{W}\right.$, Natl Grid Ref HY 239 183). Quoted sample depths (in $\mathrm{cm}$ ) relate to present water/mud interface. Coll 1975 and subm by J H Dickson.

SRR-1288. Loch of Skaill, 9 to $17 \mathrm{~cm}$
(a) inorganic
$1780 \pm 60$
(b) organic
$\delta^{13} C=+2.1 \%$
$1200 \pm 70$ $\delta^{13} C=-21.0 \%$ 
SRR-1289. Loch of Skaill, 46 to $54 \mathrm{~cm}$
(a) inorganic
$\mathbf{3 7 8 0} \pm \mathbf{7 0}$
$\delta^{1 s} C=+0.7 \%$ o
(b) organic
$2820 \pm 60$
$\delta^{1 s} C=-20.6 \%$ o

SRR-977. Loch of Skaill, 81 to $89 \mathrm{~cm}$
(a) inorganic
$4610 \pm 50$
$\delta^{1 s} C=+0.3 \%$ o
(b) organic
$\mathbf{4 0 3 0} \pm \mathbf{7 0}$
$\delta^{13} C=-18.8 \%$ 。

SRR-978. Loch of Skaill, 121 to $129 \mathrm{~cm}$
(a) inorganic
$5550 \pm 60$ $\delta^{13} C=+0.7 \%$ o
(b) organic
$5030 \pm 100$ $\delta^{15} C=-19.1 \%$

SRR-979. Loch of Skaill, 161 to $169 \mathrm{~cm}$
(a) inorganic
$\mathbf{7 8 9 0} \pm \mathbf{6 0}$
$\delta^{13} C=-2.0 \%$
(b) organic
$7120 \pm 70$ $\delta^{1 s} C=-19.3 \%$

SRR-980. Loch of Skaill, 187 to $195 \mathrm{~cm}$
(a) inorganic
$\mathbf{8 8 9 0} \pm \mathbf{7 0}$ $\delta^{1 s} C=-2.0 \%$ 。
(b) organic
$8620 \pm 90$
$\delta^{13} C=-17.2 \%$

General Comment: presence of marl, shells, and Chara oospores in sediment matrix is clear evidence of hard water environment. Consequently, two carbonaceous fractions were analyzed for each sample viz, a) 'inorganic'- $\mathrm{CO}_{2}$ evolved on digestion with $2 \mathrm{M} \mathrm{HCl}$; b) 'organic'- $\mathrm{CO}_{2}$ recovered via high pressure oxidation of acid washed residue. An interpretation of these data in terms of true age/depth relationship is described in Appendix 2 of Keatinge and Dickson (1979).

\section{Ayna Region series}

$$
\text { K. Spain }
$$

Charcoal in secs cut through valley fill deposits of Ayna region, SE Spain. Coll 1973 and subm by C Vita-Finzi, Univ College London.

SRR-726. Ayna

$$
\begin{array}{r}
\mathbf{8 2 0} \pm \mathbf{4 0} \\
\delta^{13} C=-23.2 \% \text { o }
\end{array}
$$

Sample from suspected hearth at $1.5 \mathrm{~m}$ depth in sec, $2.5 \mathrm{~m}$ high, of younger valley fill in Rambla de Dilar, SE of Ayna, Spain $\left(38^{\circ} 31^{\prime} \mathrm{N}, 2^{\circ}\right.$ $\left.\mathrm{l}^{\prime} \mathrm{W}\right)$. 
SRR-727. Ayna

$860 \pm 50$

Repeat analysis on further sample as for SRR-726.

SRR-728. Lietor

$$
\delta^{1 s} C=-23.4 \%
$$

$780 \pm 110$

$\delta^{13} C=-24.7 \%$ o

Sample at $1.5 \mathrm{~m}$ depth in sec, $2.5 \mathrm{~m}$ high, of younger of two valley fills at Lietor, Ayna region $\left(38^{\circ} 35^{\prime} \mathrm{N}, 1^{\circ} 58^{\prime} \mathrm{W}\right)$.

\section{SRR-729. Molinicos}

$420 \pm 70$

Sample at $\mathrm{lm}$ depth in $3 \mathrm{~m}$ sec of younger fill overlying older fill $\mathrm{S}$ of Molinicos, Ayna region $\left(38^{\circ} 28^{\prime} \mathrm{N}, 2^{\circ} 14^{\prime} \mathrm{W}\right)$.

$$
\begin{aligned}
& \\
& 39,740+1190 \\
& \text { SRR-730. Molinicos }-1040 \\
& \delta^{13} C=-22.2 \% 0
\end{aligned}
$$

Sample at $9 \mathrm{~m}$ depth in $10 \mathrm{~m}$ sec of older fill as described for SRR-729. General Comment (C V-F): ages support those postulated, on archaeol grounds, for similar deposits in Mediterranean Basin (Vita-Finzi, 1969). Presence in Ayna area of twofold post-Tertiary alluvial sequence accords with evidence from elsewhere in Mediterranean Basin; ages obtained for two fills support suggestion that both units are latitudinally diachronous (Vita-Finzi, 1973; 1976).

\section{Lake Geneva series}

\section{Switzerland}

Organic detritus in sediment profile taken under $47.1 \mathrm{~m}$ water column in Lake Geneva $\left(46^{\circ} 15^{\prime} \mathrm{N}, 6^{\circ} 10^{\prime} \mathrm{E}\right.$ ). Quoted depths (in $\mathrm{cm}$ ) in profile relate to uppermost level recovered by Mackereth corer. Coll 1975 and subm by P W Readman and E Hogg.

\section{SRR-891. Lake Geneva, Core 7, 47 to $82 \mathrm{~cm}$$$
\begin{array}{r}
\mathbf{2 4 6 0} \pm \mathbf{8 0} \\
\delta^{13} C=-25.0 \%
\end{array}
$$ \\ SRR-892. Lake Geneva, Core 7, 465 to $505 \mathrm{~cm} \quad \delta^{13} C=-16.8 \%$ o General Comment (KMC): this core has since been dated from its palaeo- magnetic declination and inclination record. Results are, for level of SRR-891; 200 to $400 \mathrm{yr}$ and for level of SRR-892; 1600 to $2000 \mathrm{yr}$ (Hogg,} 1978).

\section{Wales}

\section{Melynllyn Tarn series}

Organic detritus in lake sediment from Melynllyn Tarn, Carneddan, North Wales $\left(53^{\circ} 10^{\prime} \mathrm{N}, 3^{\circ} 56^{\prime} \mathrm{W}\right.$, Natl Grid Ref SH 702657$)$ alt $632 \mathrm{~m}$. Samples coll using Mackereth corer (Core No. 4) and depths (in $\mathrm{cm}$ ) quoted relate to present mud/water interface. Coll 1974 and subm by G H Evans, Liverpool Polytechnic. 
SRR-634. Melynllyn Tarn, 105 to $115 \mathrm{~cm}$

Dark brown fine detritus nekron mud.

SRR-635. Melynllyn Tarn, 165 to $175 \mathrm{~cm}$

Composition as for SRR-634, but also, sample contained four narrow dark bands which were richer in iron.

SRR-636. Melynllyn Tarn, 225 to $235 \mathrm{~cm}$

Composition as for SRR-634 but with five narrow dark bands.

$$
\begin{array}{r}
\mathbf{2 6 7 0} \pm \mathbf{1 2 0} \\
\delta^{13} C=-26.1 \% \text { o }
\end{array}
$$

SRR-637. Melynllyn Tarn, 285 to $295 \mathrm{~cm}$

Composition as for SRR-634.

SRR-638. Melynllyn Tarn, 345 to $355 \mathrm{~cm}$

Composition as for SRR-634 but with two narrow dark bands.

$3420 \pm 110$

$\delta^{13} C=-28.3 \%$

$$
\begin{array}{r}
4760 \pm 90 \\
\delta^{13} C=-27.5 \%
\end{array}
$$

$7380 \pm 160$

SRR-639. Melynllyn Tarn, 405 to $415 \mathrm{~cm} \quad \delta^{13} C=-29.1 \%$

Composition as for SRR-634.

General Comment (GHE): preliminary palaeoproductivity studies based on absolute numbers of diatoms deposited per $\mathrm{cm}^{2}$ of mud shows fluctuations in diatom production during Devensian time. In general, productivity reached highest values in top $125 \mathrm{~cm}$ of deposit.

It is significant that at Melynllyn, date of alder rise (SRR-639) appears to be much earlier than at Nant Ffrancon, less than $8 \mathrm{~km}$ away $(6884 \pm 110 ;$ Q-900). Much closer agreement is found for age of elm decline (SRR-638) and at Nant Ffrancon $5054 \pm 70$; Q-904. SRR-634 appears to be anomalous and is difficult to explain since there is no supporting evidence to suggest that man had a disturbing influence in this basin.

\section{Llyn Padarn series}

Lake sediments from Llyn Padarn $\left(58^{\circ} 8^{\prime} \mathrm{N}, 4^{\circ} 10^{\prime} \mathrm{N}\right.$, Natl Grid Ref SM 581 606). Samples coll by Mackereth corer from deepest part of lake (ca 22m water column). Quoted depths (in $\mathrm{cm}$ ) relate to water/mud interface. Coll 1973 and subm by S Guppy, Univ College North Wales.

SRR-406. Llyn Padarn, 180 to $200 \mathrm{~cm}$

SRR-407. Llyn Padarn, 390 to $410 \mathrm{~cm}$

SRR-408. Llyn Padarn, 580 to $600 \mathrm{~cm}$

$$
\begin{array}{r}
1470 \pm \mathbf{8 0} \\
\delta^{1 s} C=-29.3 \% o \\
\mathbf{3 5 8 0} \pm \mathbf{8 0} \\
\delta^{13} C=-28.4 \% o \\
\mathbf{7 0 7 0} \pm \mathbf{8 0} \\
\delta^{13} C=-27.8 \% o
\end{array}
$$

General Comment (SG): ages agree well with palaeomagnetic pattern measured by R Thompson, Univ Edinburgh (written commun). 


\section{Llyn Peris series}

Lake sediments from Llyn Peris $\left(53^{\circ} 8^{\prime} \mathrm{N}, 4^{\circ} 10^{\prime} \mathrm{N}\right.$, Natl Grid Ref SM 589 598). Coll 1973 and subm by S Guppy.

SRR-409. Llyn Peris, 110 to $130 \mathrm{~cm}$

$$
\begin{array}{r}
\mathbf{7 7 0} \pm \mathbf{7 0} \\
\delta^{1 s} C=-28.7 \% 0 \\
\mathbf{8 2 0} \pm \mathbf{6 0} \\
\delta^{1 s} C=-29.2 \%
\end{array}
$$

SRR-410. Llyn Peris, 210 to $240 \mathrm{~cm}$

General Comment (SG): ages obtained for these sediments are older than expected. Vertical mixing of sediment column due to partial infill by quarry waste seems likely. Sharp peak in $\mathrm{Cu}$ concentration, resulting from mid-19th century mining in area, occurs at 0.9 to $1.1 \mathrm{~m}$ depth.

\section{N. West Indies \\ Barkers Peninsula series, Grand Cayman Island}

Mangrove swamp peat (mainly fibers from Rhizophora mangle L) in cores taken on seaward ( $\mathrm{N}$ to $\mathrm{S}$ ) transept from $\mathrm{N}$ shore of Barkers Peninsula $\left(19^{\circ} 28^{\prime} \mathrm{N}, 81^{\circ} 22^{\prime} \mathrm{W}\right)$. Quoted depth increments (in $\mathrm{cm}$ ) relate to mean sea level. Coll 1976 by C D Woodroffe; subm by D R Stoddart, Univ Cambridge.

SRR-1002. Barkers Peninsula, 179 to $184 \mathrm{~cm}$ $2130 \pm 40$

Core taken $65.5 \mathrm{~m} \mathrm{~S}$ from $\mathrm{N}$ shore.

SRR-1003. Barkers Peninsula, 42 to $47 \mathrm{~cm}$

Core taken $21.3 \mathrm{~m} \mathrm{~S}$ from $\mathrm{N}$ shore. $\delta^{1 s} C=-27.1 \%$

SRR-1004. Barkers Peninsula, 204 to $209 \mathrm{~cm}$ Core taken $67.1 \mathrm{~m} \mathrm{~S}$ from $\mathrm{N}$ shore.

SRR-1005. Barkers Peninsula, 140 to $145 \mathrm{~cm}$ Core taken $69.3 \mathrm{~m} \mathrm{~S}$ from $\mathrm{N}$ shore.

$$
\mathbf{8 4 0} \pm \mathbf{5 0}
$$
$\delta^{13} \mathrm{C}=-26.2 \%$

$$
930 \pm 80
$$
$\delta^{13} C=-26.2 \%$

$$
2160 \pm 80
$$
$\delta^{1 s} C=-26.4 \%$ 。

SRR-1006. Barkers Peninsula, 108 to $113 \mathrm{~cm}$ Core taken $61 \mathrm{~m} \mathrm{~S}$ from $\mathrm{N}$ shore.

SRR-1007. Barkers Peninsula, 45 to $50 \mathrm{~cm}$ Core taken $31.2 \mathrm{~m} \mathrm{~S}$ from $\mathrm{N}$ shore.

$$
1400 \pm 50
$$
$\delta^{13} C=-26.5 \%$ $\mathbf{5 7 0} \pm \mathbf{6 0}$
$\delta^{13} C=-26.6 \% \circ$

SRR-1008. Barkers Peninsula, 111 to $116 \mathrm{~cm}$ Core taken $33.5 \mathrm{~m} \mathrm{~S}$ from $\mathrm{N}$ shore.

SRR-1009. Barkers Peninsula, 109 to $114 \mathrm{~cm}$ $\delta^{13} C=-26.3 \%$ Core taken $45.7 \mathrm{~m} \mathrm{~S}$ from $\mathrm{N}$ shore. 


\section{SRR-1010. Barkers Peninsula, 125 to $130 \mathrm{~cm} \quad \delta^{13} C=-26.5 \%$}

Core taken $53.3 \mathrm{~m} \mathrm{~S}$ from $\mathrm{N}$ shore.

General Comment (DRS): all samples are from contact between mangrove peat and limestone bedrock. Ages should indicate initiation of mangrove growth in response to sea-level rise. Seven ages show linear age/depth relationship suggesting sea-level rise of $1 \mathrm{~m} / 1300 \mathrm{yr}$. SRR-1004 and -1010 are anomalously young, possibly as result of root contamination. Site of SRR-1004 has been re-examined, and peat at this point may be contained within narrow deep bedrock cavity and may have isolated history. Inferred rate of rise in sea level agrees with dates from similar mangrove environments elsewhere in West Indies and Caribbean.

\section{REFERENCES}

Bath, A H, Edmunds, W M, and Andrews, J N, 1979, Palaeoclimatic trends deduced from the hydrochemistry of a Triassic sandstone aquifer, United Kingdom, in Isotope hydrology, 1978, v 2: Vienna, IAEA, p 545-568.

Beckett, S C and Hibbert, F A, 1976, An absolute pollen diagram from the Abbot's Way: Somerset Levels Papers, no. 2, p 24-27.

Broecker, W S and Olsen, E A, 1961, Lamont radiocarbon measurements VII: Radiocarbon, v 3, p 176 to 204.

Browne, M A E, Harkness, D D, Peacock, J D, and Ward, R G, 1977, The date of deglaciation of the Paisley-Renfrew area: Scottish Jour Geol, v 13, no. 4, p 301-303.

Calvert, S E and Morris R J, 1977, Geochemical studies of organic rich sediments from the Namibian Shelf. II, Metal-organic associations: Deep-Sea Research, Deacon vol, p $667-680$.

Coles, J M and Hibbert, F A, 1968, Prehistoric roads and tracks in Somerset, England: 1. Neolithic: Prehist Soc Proc, v 34, p 238.

Coles, J M, Hibbert, F A, and Clements, C F, 1970, Prehistoric roads and tracks in Somerset, England: 2. Neolithic: Prehist Soc Proc, v 36, p 125-151.

Coles, J M, Hibbert, F A, and Orme, B J, 1973, Prehistoric roads and tracks in Somerset, 3. The Sweet Track: Prehist Soc Proc, v 39, p 256-293.

Coles, J M and Coles, M M, 1975, Check list of radiocarbon dates relating to archaeological sites in the levels: Somerset Levels papers no. 1. Hertford, Stephen Austin and Sons Ltd.

Coles, J M and Orme, B J, 1976, The Meare Heath Trackway; excavation of a Bronze Age structure in the Somerset Levels: Prehist Soc Proc, v 42, p 293-318.

Coope, G R and Pennington, W, 1977, The Windermere interstadial of the Late Devensian: Royal Soc [London] B, Philos Trans, v 280, p 337-339.

Creer, K M, Readman, P W, and Papamarinopoulos, S P, in press, Geomagnetic secular variations in Greece through the last 6000 years obtained from lake sediment records: Geophys Jour Royal Astron Soc, in press.

Dimbleby, G W, 1953, Natural regeneration of pine and birch on the heather moors of North-East Yorkshire: Forestry, v 24, no. 1, p 41-52.

Donner, J J, Jungner, H, and Vasari, Y, 1971, The hard-water effect on radiocarbon measurements of samples from Säynäjlämpi, North-East Finland: Soc Sci Fenn Comm Phys-Math, v 41, p 307-310.

Flenley, J R, 1980, The tropical rain forest, a geological history: London, Butterworth Press.

Gaskell, S J, Morris, R J, Eglington, G, and Calvert, S E, 1975, The geochemistry of a recent marine sediment off northwest Africa. An assessment of source of input and early diagenesis: Deep-Sea Research, v 22, p 777-789.

Harland, R, Gregory, D M, Hughes, M J, and Wilkinson, I P, 1978, A late Quaternary bio- and climatostratigraphy for marine sediments in the north-central part of the North Sea: Boreas, v 7, p 91-96.

Hicks, S P, 1975, Variations in pollen frequency in a bog at Kangerjoki, N E Finland, during the Flandrian: Soc Sci Fenn Comm Biol, v 80, p 27.

Hogg, T E, ms, 1978, The Holocene geomagnetic field in Europe: PhD thesis, Univ Edinburgh. 
Keatinge, T H and Dickson, J H, 1979, Mid-Flandrian changes in vegetation on Mainland Orkney: New Phytol, v 82, p 585-612.

Matthews, J A, 1974, Families of lichenometric dating curves from the Storbreen gletschervorfeld, Jotunheimen, Norway: Norsk geog tidsskrift, v 28, p 215-235.

1975 , Experiments on the reproducibility and reliability of lichenometric dates, Storbreen gletschervorfeld, Jotunheimen, Norway: Norsk geog tidsskrift, v 29, p 97-109.

1977, A lichenometric test of the 1750 end-moraine hypothesis; Storbreen gletschervorfeld, southern Norway: Norsk geog tidsskrift, v 31, p 129-136.

Morley, R J, in press a, The palaeoecology of Tasek Bera, a lowland swamp in Pahang, W Malaysia: Jour Tropical Geog, in press.

in press $b$, The origin and history of Tasek Bera, in Furtado, $J$ and Mori, S, eds, The ecology of a tropical freshwater swamp, the Tasek Bera, Malaysia, with special reference to biological production: The Hague, Junk, in press. in press c, Changes of dry-land vegetation in the Kerinci area of Sumatra during the Late Ouaternary Period, in ICP Symposium vol, 4th: Lucknow, in press.

Morris, R J and Calvert, S E, 1977, Geochemical studies of organic rich sediments from the Namibian Shelf, I. The organic fractions: Deep-Sea Research, Deacon vol, p 647-665.

O'Sullivan, P E, 1976, Pollen analysis and radiocarbon dating of a core from Loch Pityoulish, Eastern Highlands of Scotland: Jour Biogeog, v 3, p 293-302.

Page, N R, 1972, On the age of the Hoxnian interglacial ' Geol Jour, v 8, p 129-142.

Pennington, W, 1975a, Council for British Archaeology: Research Rept 11, p 83. $1975 \mathrm{~b}$, A chronostratigraphic comparison of Late-Weichselian and LateDevensian subdivisions, illustrated by two radiocarbon dated profiles from Western Britain: Boreas, v 4, p 157-171.

1977, The Late Devensian flora and vegetation of Britain: Royal Soc [London] B, Philos Trans v 280, p 247-271.

Pennington, W, Cambray, R S, Eakins, J D, and Harkness, D D, 1976, Radionuclide dating of recent sediments from Blelham Tarn: Freshwater Biol, v 6 p 317-331.

Sugden, D E and John, B S, 1973, in van Zinderen Bakker E M, Sr, ed, Palaeoccology of Africa, the surrounding islands and Antarctica: Cape Town, Balkema, p 139 to 159.

Thompson, R, 1973, Palaeolimnology and palaeomagnetism: Nature, v 242, p 182-184.

Turner, J, Heweston, V P, Hibbert, F A, Lowry, K H, and Chambers, C, 1973, The history of the vegetation and flora of Witteybank Fell and the Cow Green Reservoir Basin: Royal Soc [London] B, Philos Trans, v 265, p 327-408.

Vita-Finzi, C, 1969, The Mediterranean valleys: Cambridge, Cambridge Univ Press. 1973, Recent earth history: London, Macmillan. 219.

Wardroper, A M K, Maxwell, J R, and Morris, R J, 1978, Sterols of a diatomaceous ooze from Walvis Bay: Steroids, v 32, no. 2, p 203-221.

Williams, W, ms, 1977, The Flandrian vegetational history of the Isle of Skye and the Morar Peninsula: PhD thesis, Univ Cambridge.

\section{ERratum}

Throughout Section C of Scottish Universities Research and Reactor Centre Radiocarbon Measurements III (R, 1979, v 21, p 203-256) Ecuador is misspelled. Apologies are due to $\mathrm{C}$ R Bristow, Inst Geol Sci, London for any inconvenience that may have resulted from this error which was introduced into his original report during typing and completion of the manuscript.

Attention has also been drawn to the fact that ages for the obsidian fragments as discussed in the general comment to SRR-438 and -439 of the same list were assessed from hydration rate measurements and not by $\mathrm{K} /$ Ar dating as reported. 